\title{
Pressures on Boreal Riparian Vegetation: A Literature Review
}

\author{
Jacqueline H. T. Hoppenreijs ${ }^{\star t}$, R. Lutz Eckstein ${ }^{t}$ and Lovisa Lind ${ }^{\dagger}$ \\ Department of Environmental and Life Sciences, Karlstad University, Karlstad, Sweden
}

Riparian zones are species-rich and functionally important ecotones that sustain physical, chemical and ecological balance of ecosystems. While scientific, governmental and public attention for riparian zones has increased over the past decades, knowledge on the effects of the majority of anthropogenic disturbances is still lacking. Given the increasing expansion and intensity of these disturbances, the need to understand simultaneously occurring pressures grows. We have conducted a literature review on the potential effects of anthropogenic pressures on boreal riparian zones and the main processes that shape their vegetation composition. We visualised the observed and potential consequences of flow regulation for hydropower generation, flow regulation

OPEN ACCESS

Edited by:

Björn Kristian Klatt, Lund University, Sweden

Reviewed by:

José Maria Santos,

University of Lisbon, Portugal

Michael Alister Reid,

University of New England, Australia

*Correspondence:

Jacqueline H. T. Hoppenreijs jacqueline.hoppenreijs@kau.se

tORCID:

Jacqueline H. T. Hoppenreijs orcid.org/0000-0002-4284-5453

R. Lutz Eckstein

orcid.org/0000-0002-6953-3855

Lovisa Lind

orcid.org/0000-0002-7212-8121

Specialty section:

This article was submitted to

Biogeography and Macroecology,

a section of the journa

Frontiers in Ecology and Evolution

Received: 31 October 2021

Accepted: 22 December 2021

Published: 31 January 2022

Citation:

Hoppenreijs JHT, Eckstein RL and Lind $L$ (2022) Pressures on Boreal Riparian Vegetation: A Literature Review. Front. Ecol. Evol. 9:806130. doi: $10.3389 /$ fevo.2021.806130 through channelisation, the climate crisis, forestry, land use change and non-native species in a conceptual model. The model shows how these pressures change different aspects of the flow regime and plant habitats, and we describe how these changes affect the extent of the riparian zone and dispersal, germination, growth and competition of plants. Main consequences of the pressures we studied are the decrease of the extent of the riparian zone and a poorer state of the area that remains. This already results in a loss of riparian plant species and riparian functionality, and thus also threatens aquatic systems and the organisms that depend on them. We also found that the impact of a pressure does not linearly reflect its degree of ubiquity and the scale on which it operates. Hydropower and the climate crisis stand out as major threats to boreal riparian zones and will continue to be so if no appropriate measures are taken. Other pressures, such as forestry and different types of land uses, can have severe effects but have more local and regional consequences. Many pressures, such as non-native species and the climate crisis, interact with each other and can limit or, more often, amplify each other's effects. However, we found that there are very few studies that describe the effects of simultaneously occurring and, thus, potentially interacting pressures. While our model shows where they may interact, the extent of the interactions thus remains largely unknown.

Keywords: riparian vegetation, boreal, hydropower, forestry, climate change, land use change (LUC), invasion, ecosystem interactions

\section{INTRODUCTION}

Riparian zones are as important for ecosystems and their functioning, as they are vulnerable to a multitude of direct and indirect stressors caused by human activities (Naiman et al., 2005; Stella and Bendix, 2019). Forming on the interface of land and freshwater, the riparian zone (Figure 1) is often defined as the area between the low- and high-water mark along streams and lakes plus the part of the landscape that is above the high-water mark but still in direct exchange with the water table 


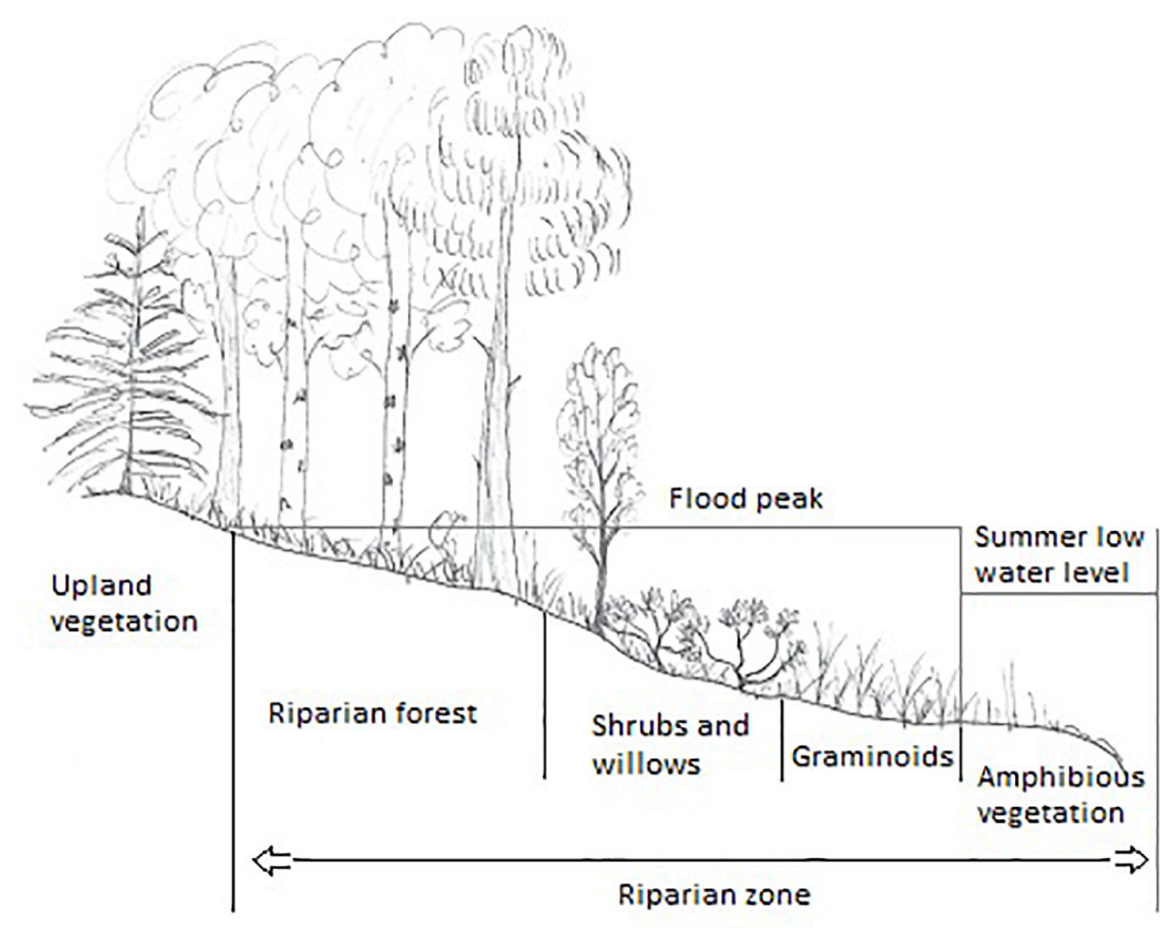

FIGURE 1 | Vertical zonation in boreal riparian zones. Image by Lovisa Lind.

(Naiman et al., 2005). Variation in regional and local geomorphology, and the consequent impacts of flow and sedimentation regimes, cause high heterogeneity in riparian zones through changing the recruitment of and dynamics within the riparian zone (Vesipa et al., 2017). This heterogeneity is the basis for a species-rich plant community that contributes to local and regional diversity (Nilsson and Svedmark, 2002; Sabo et al., 2005) and provides many other organisms with resources (e.g., Bennett et al., 2014; Johnson and Almlöf, 2016). Additionally, riparian zones and their vegetation fulfil a disproportionately large role in the functioning of fluvial landscapes, for example by physical and chemical buffering and cycling.

This review focusses on riparian vegetation in the boreal zone, an area that is characterised by a short growing season (3-6 months), cool summers, long, cold and snow-rich winters (Pfadenhauer and Klötzli, 2020), and year-round precipitation with a peak in summer (Beck et al., 2018). The boreal zone is delimited by the $10^{\circ} \mathrm{C}$-isotherm in the north and the $18^{\circ} \mathrm{C}$ isotherm in the south and stretches across North America, Scandinavia and Russia (Pfadenhauer and Klötzli, 2020). The geology of the boreal zone with respect to the lithosphere is very variable and consists largely of continental crusts or sedimentary rocks from the Archean to the Cenozoic era (OneGeology, 2020). Large parts of the boreal zone consist of mountains or are covered by mires, and most soils were shaped during the latest ice age and developed during the Holocene, on unconsolidated rocks such as loess, moraines and fluvio-glacial sediments (Pfadenhauer and Klötzli, 2020). In boreal systems, year-round precipitation and relatively low temperatures assure year-round flow in most rivers, but variation between years can be large (Woo et al., 2008).
The melting of ice and snow at the end of winter marks the beginning of the spring flood, which is the peak flow in this climatic zone (Lindström, 1993). Flow is lowest during summer, when evapotranspiration is highest, increases due to increased precipitation in autumn, only to decrease again when winter commences and rivers (partly) freeze. Freezing can take place on the water surface or from below, and the formation of ice dams can cause high water levels in the stream and flooding or ice formation in riparian zones (Lind et al., 2014a). Boreal riparian zones are thus characterised by a natural disturbance regime, in which parts of the riparian vegetation get scoured away by ice or flooding, and sediments are deposited annually (Nilsson and Svedmark, 2002; Yarnell et al., 2015). These processes lead to a zonation of the vegetation (Figure 1), with vegetation belts forming mainly based on the frequency and intensity of flooding. In addition, local factors, such as high connectivity with the groundwater table, can alter chemical cycling and circumstances in the riparian zone to the extent that plant species richness increases (Kuglerová et al., 2014b). Water and material are also received from upland habitat via surface runoff or subsurface flow, which means that the riparian zone is tightly connected with all of its surroundings and a hotspot for the conversion, transportation and storage of water and material in fluvial systems (Naiman and Décamps, 1997).

The connectedness of riparian zones to its adjacent streams and upland habitats makes them, and their vegetation, vulnerable to changes in their environment. Riparian zones themselves have since long been exploited by people, for example for agriculture or herding, as a means to access water or for extraction of raw materials (Naiman et al., 2005; Langston, 2013). However, 
increasingly intensive and large-scale activities, both in-stream and upland, such as damming and forestry, respectively, affect local and regional processes (Bejarano et al., 2020b; Kuglerová et al., 2021). These separate pressures, combined with global pressures such as the climate crisis (Nilsson et al., 2013), have had, and continue to have, profound effects on the composition and functioning of riparian vegetation.

Scientific interest for riparian vegetation has increased over the past decades, to the point where it has become a rather welldescribed topic (Dufour et al., 2019; Rood et al., 2020). Dufour et al. (2019) recognise, however, that the topic remains quite scattered, and found that the geographical and climatological spread of studies is far from equal: most work describes systems in North America and Europe, and in temperate or drier zones. Some areas are relatively understudied, such as parts of Russia and North America, because they are remote, (relatively) pristine or both, whereas other areas, such as boreal Sweden and Finland, receive relatively much attention. Studies often describe limited spatial and temporal scales and multiple stressors and pressures on riparian vegetation, a trend that is also recognised by other authors (Stella and Bendix, 2019). That entanglement means that there is a lack of insight in what the individual effects of these pressures are, and which patterns are observed because of additive, synergistic or antagonistic effects (Stella and Bendix, 2019).

Here, we aim: (1) to conduct and present a literature review (Grant and Booth, 2009) on the state of knowledge on the different pressures on boreal riparian vegetation, and how these interact. We present a conceptual model (Miro, 2021) in which we (2) visualise the effects of these pressures on the main processes that build up, maintain and break down riparian vegetation. We also (3) review the potential consequences of these changed processes on specific groups of plants. We used Google Scholar as a starting point to search recent and current, English-written scientific literature on pressures on boreal riparian vegetation and searched for additional literature by using the reference and citation lists of the initial results. This resulted in 145 original papers, 23 reviews, 12 reports and 2 books that describe these pressures and the ecological processes they affect or are expected to affect, or their effects on the vegetation itself. In total, we found 182 sources describing lab, field and modelling research on the effects of flow regulation for hydropower generation, flow regulation through channelisation, the climate crisis, forestry, land use change and non-native species on riparian vegetation and vegetation-shaping processes (Stella and Bendix, 2019; Rood et al., 2020; Laudon et al., 2021; Singh et al., 2021).

\section{PRESSURES AND THEIR EFFECTS ON BOREAL RIPARIAN VEGETATION}

\section{Flow Regulation for Hydropower Generation}

Regulation of natural flow regimes for freshwater storage, flood control and transport is a widespread phenomenon (Naiman et al., 2005). During the $20^{\text {th }}$ century, generation of energy has been the predominant reason for the building of in-stream infrastructure across the boreal zone. For example, flowing water is the third largest source for energy production in Sweden (Energimyndigheten, 2020) and the largest source for energy production in Canada (Natural Resources Canada, 2020). Nilsson et al. (2005) report that large river systems in boreal areas are relatively little affected by damming activities, when compared to those in other climatic zones, except in Sweden. Hydropower will also become more important in the future, as plans for an energy transition continue to be developed (e.g., Couto and Olden, 2018; Smokorowski, 2021). While hydropower is a renewable form of energy, its negative effects on natural ecosystems and on other ecosystem services, are many and welldocumented (e.g., Renöfält et al., 2010; Tonkin et al., 2018). Hydropower infrastructure can be used for decades and causes altered geomorphology (Englund and Malmqvist, 1996), changed flow regimes (Nilsson and Svedmark, 2002) and decreased longitudinal connectivity (Jansson et al., 2000b) by dividing rivers in dam-to-dam ecosystem fragments rather than well-connected entities (Wohl, 2017). Dams in run-of-the-river systems are often built at rapids to use the naturally present streambed height difference, and the rapids are often bypassed, causing them to fall dry (Renöfält et al., 2010). The placement of dams at these rapids also means that upstream, lotic river fragments become lentic and experience little variation in water levels (Figure 2). They turn into reservoirs, or reservoir-like river stretches, and while the water level fluctuations previously were large on a seasonal scale and small on a daily basis, there will be hardly any seasonal variation left after the regulation (Englund and Malmqvist, 1996; Arheimer et al., 2017). There is a spectrum of flow regulation types and intensities with which hydropower is generated, with, for example, run-of-river being less intensive than hydropeaking (Bejarano et al., 2018a). Depending on the type of regulation, variation in flow is then higher on a weekly, daily or sub-daily basis than on a seasonal basis.

Hydropeaking (Figure 2) is an often-applied form of water level regulation that leads to variation on a sub-daily basis. The frequent inundation caused by hydropeaking leads to soil waterlogging and submergence of plants that causes slow gas diffusion, rapid light attenuation and anoxia (Armstrong et al., 1994; Bejarano et al., 2018a). Next to that, hydropeaking leads to frequent water shortage, especially during low flow conditions, which also causes plant stress. These are quite general effects on plants, but hydropeaking can also have negative effects on plants' germination success in the riparian zone, and their subsequent establishment, resulting in vegetation communities that are especially poor in flooding-intolerant plants (Bejarano et al., 2020b) and richer in competitive species (Aguiar et al., 2018). Increased flow regulation leads to changes in germination, establishment and growth (Bejarano et al., 2018a; Greet et al., 2020), to a lower species richness locally (Nilsson and Jansson, 1995) and lower abundance of all plant life forms in general, and of non-woody species in particular (Bejarano et al., 2020a). With a flooding regime that changes from high amplitude to high frequency, the riparian zone, whose width is determined by the spring flood, becomes narrower. Hence, another direct and local 


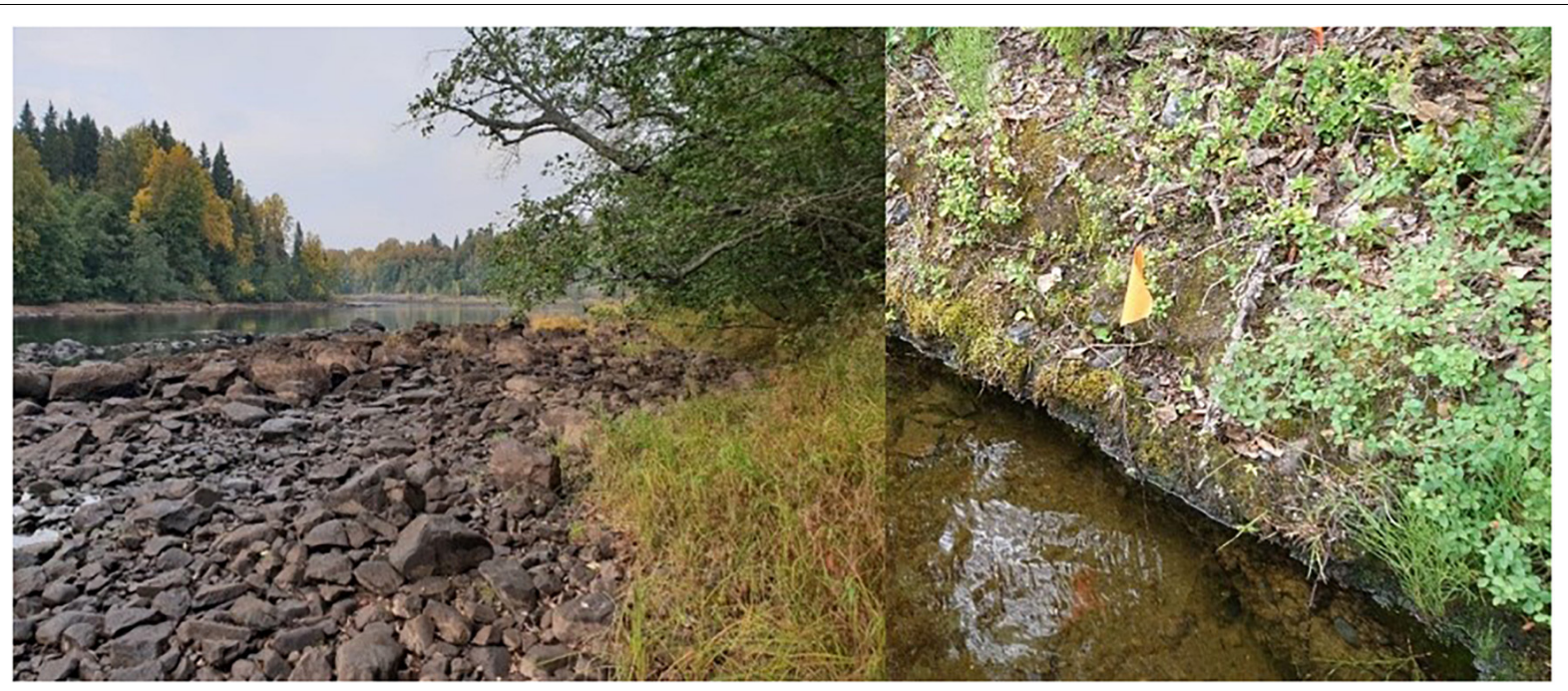

FIGURE 2 | (Left) View over the regulated Västerdal River, Sweden. Photo by LL. (Right) A riparian zone undergoing hydropeaking in Ume River, Sweden. Photo by JH.

consequence of hydropower is the decrease in riparian space. While this is not reported in literature yet, this decrease may lead to a decrease of riparian species in a similar way as is predicted to happen with decreased riparian extent as a consequence of climatic change (Ström et al., 2012; Jansson et al., 2019). These effects are visualised in Figure 3, where "Flow regulation for hydropower regulation" affects the amplitude, timing, frequency and duration of floods, which in turn affects the extent of the riparian zone and processes therein, such as plant growth.

These local changes in the riparian vegetation community are often (but not always, see Nilsson and Jansson, 1995, and Jansson et al., 2000a) reflected on the regional scale, with many studies demonstrating changes in riparian vegetation composition along regulated rivers, compared to free-flowing rivers (e.g., Nilsson et al., 1991, 1997; Jansson et al., 2000b). These changes, often in the form of decreased species richness within, but not necessarily across, river fragments, can be caused by dams physically disconnecting river fragments from each other (see "Infrastructure" in Figure 3). Each dam limits the transport of sediments and nutrients, which leads to upstream accumulation and a relative deficit downstream (Hauer et al., 2018). The lower flow velocity downstream of the dam also decreases erosion and transport distance of materials, leading to a relatively larger deficit locally although local circumstances can change such patterns, such as abundant vegetation that retains sediments (Vesipa et al., 2017). Dam infrastructure thus changes resource availability through multiple mechanisms, but it also affects biota and biotic populations through limitation of migration of organisms and dispersal of plant propagules (Andersson et al., 2000b; Mallik and Richardson, 2009; Renöfält et al., 2010). While many studies suggest that dams reduce species richness in and similarity between impoundments (Andersson et al., 2000a; Merritt and Wohl, 2006; Nilsson et al., 2010), there is evidence that hydrochory from within-impoundment sources can compensate for decreased dispersal between impoundments, leading to similar amounts of water-dispersed propagules in impounded and free-flowing rivers (Jansson et al., 2005).

Timing and duration of flooding can also change vegetation composition and functional diversity (Lozanovska et al., 2020). During a rise in discharge, vegetative propagules and seeds could become washed out and transported downstream, and later strand during decreasing discharge (Bejarano et al., 2018a). Sarneel et al. (2016) found that the timing of arrival of seeds does affect their chances for germination and growth, meaning that priority effects, i.e., the advantage that already present or early-arriving species have over later-arriving species, can put hydrochorous species at a disadvantage when compared to species that rely on other forms of dispersal. Hydrochory is extensively studied as a factor that affects local and regional species richness and hydrochorous species specifically (Jansson et al., 2000b; Merritt et al., 2010), and is one of the mechanisms driving riparian vegetation to become less species-rich and, probably, also functionally poorer with increasing regulation for hydropower purposes (Poff and Zimmerman, 2010; Bejarano et al., 2018b). While much of the work on riparian vegetation in boreal ecosystems has been done in northern Sweden, it is suggested that similar mechanisms drive changes in boreal riparian communities elsewhere (Dynesius et al., 2004).

Given that regulation for hydropower generation, in whichever form, changes the processes that underlie the structure of riparian vegetation, its effects are diverse but tremendous. While it is difficult to generalise, there is sufficient literature (e.g., Nilsson et al., 1997; Jansson et al., 2000a) to support the hypothesis that species and groups of species with specific traits decrease in abundance or become locally or regionally extinct. The fact that regulation is widespread and that it has both local and regional effects wherever it occurs, also means that its interactions with other pressures are manifold. These interactions will be discussed at the respective pressures throughout this paper. 


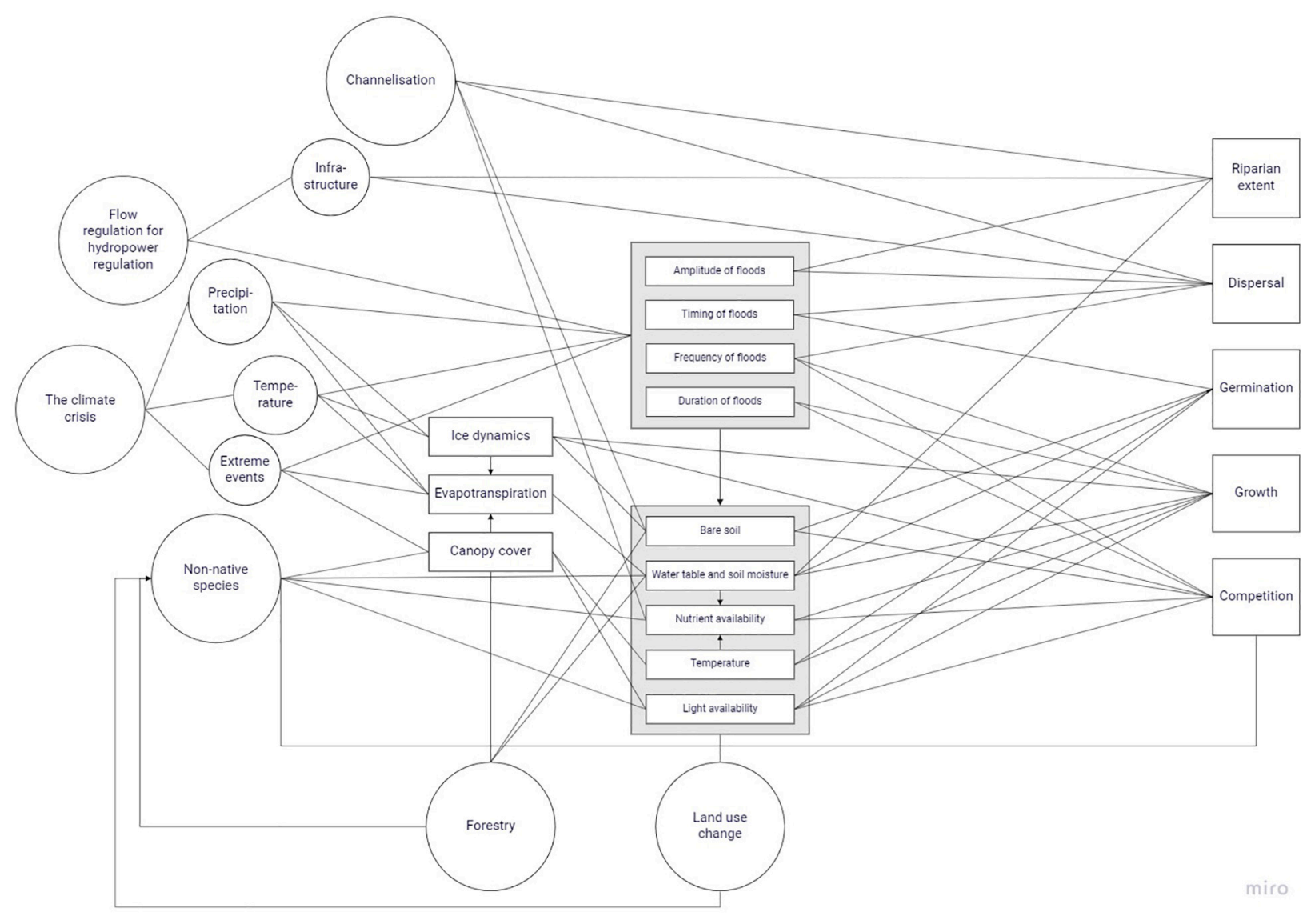

FIGURE 3 | Conceptual model of the main potential effects of anthropogenic pressures on processes and habitats in the boreal riparian zone. Circles are pressures and pressure components, rectangles are intermediates, partially grouped as belonging to the flow regime (upper shaded rectangle) or the microhabitat (lower shaded rectangle), and squares are characteristics of and processes in the riparian zone. Lines and arrows represent effects and can be positive or negative. The effects of "Ice dynamics" change over time with initial intensification of the dynamics and eventual decrease with increasing climatic change.

\section{Flow Regulation Through Channelisation}

While some rivers are regulated for hydropower purposes, others have been adjusted for timber floating. From the mid-nineteenth century until the 1970s (parts of) many boreal rivers in Scandinavia were channelised to facilitate timber floating (Gardeström et al., 2013). Boulders were removed and riverbeds were narrowed and smoothened (Figure 4) to speed up downstream transport of logs (Muotka and Syrjänen, 2007). This simplification of the channel morphology led to higher flow velocity and different flooding dynamics in the riparian zone (Nilsson et al., 2005), and resulted in increased longitudinal connectivity whereas vertical and lateral connectivity decreased (Wohl, 2017).

The fluvial effects of channelisation are often opposite to those of damming, as flow velocity increases and residence time of water in the channel thus decreases. The increased longitudinal connectivity also increases the distance over which sediment and, potentially, other material such as plant propagules, are transported in a certain amount of time (Figure 3; Nilsson et al., 2010). We did not find any research that describes direct effects of increased longitudinal connectivity on the composition of riparian vegetation.

The degree to which the riparian zone is affected by instream changes also depends on the lateral connectivity between stream and riparian zone. The placement of boulders on riverbanks means that there is less space for riparian plants to establish in channelised streams (Figure 3). Helfield et al. (2007) found that channelised streams have a lower frequency of low-intensity floods when compared to restored channels, meaning that these boulders have also hampered the deposition of sediment, nutrients and, probably, plant propagules. High flow velocity is usually related to decreased deposition (e.g., Wohl and Beckman, 2014), which means that riparian zones along channelised streams in boreal areas may be prone to relatively large depletion effects. This further decreases opportunities for establishment and growth of riparian vegetation. Decreased nutrient availability may affect some species more than others, which may cause shifts in riparian community composition. Erosion of the riparian zone is unlikely in parts of the channel where artificial channel structures are in place, but more likely in places without such structures, because of the higher flow velocity 


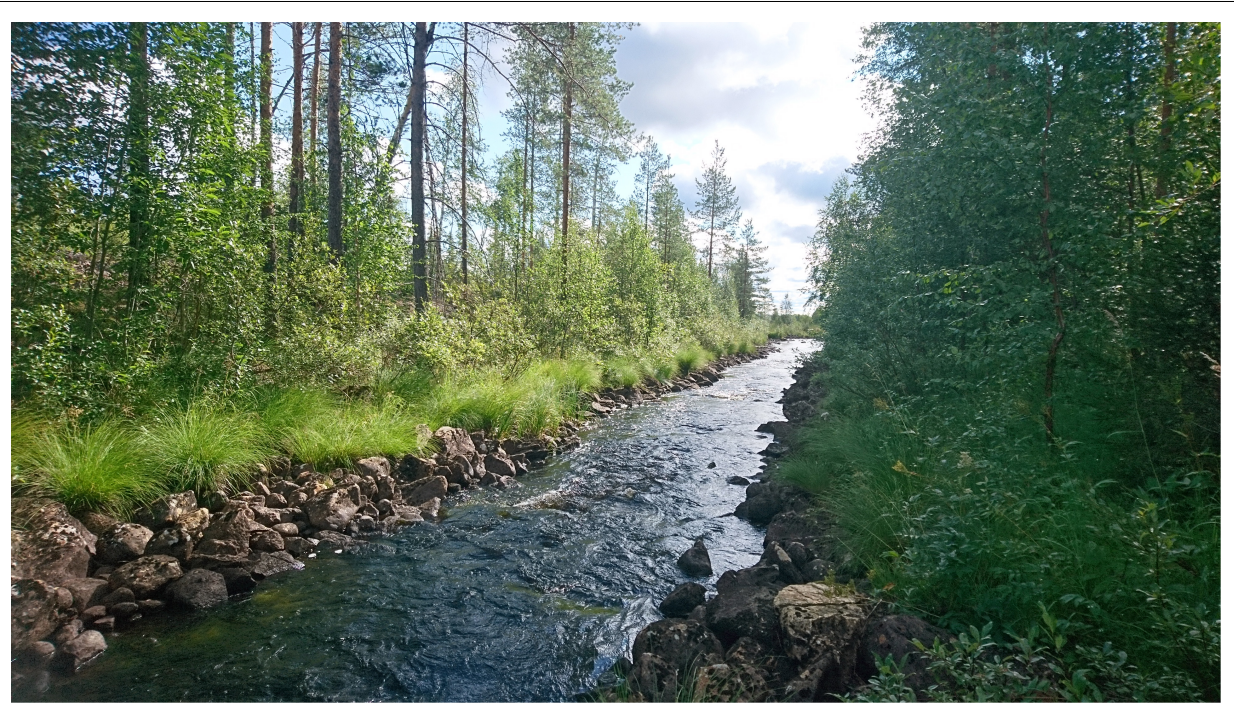

FIGURE 4 | Bjurbäcken, a channelised tributary to Vindel River, Sweden. Photo by Jacqueline Hoppenreijs.

(Kuglerová et al., 2017). The lower disturbance rate caused by the boulders on riverbanks likely also resulted in fewer open patches and thus even fewer opportunities for plant establishment (Kuglerová et al., 2017). Therefore, there will be fewer plant propagules released from the riparian zone into the stream. Since spreading of plant propagules via water is an important driver of riparian plant species richness (Jansson et al., 2005), it is likely that this has caused riparian vegetation to change during the years during which streams were channelised.

We do not know of any literature that looks at the effects of channelisation on pristine riparian vegetation. Knowledge on effects of channelisation on boreal streams is largely obtained through comparison of channelised with natural or restored streams. This lack of knowledge has resulted in few BACI (before-after-control-impact) designs being published (but see Nilsson et al., 2015a for some before-after studies on other taxa), and space-for-time substitutions (e.g., Hasselquist et al., 2015; Dietrich et al., 2016) are being used to overcome this lacuna. Most literature supports the hypothesis that restoration has or will have positive effects on riparian vegetation and, thus, that channelisation has had negative effects (e.g., Helfield et al., 2007; Hasselquist et al., 2015). Not all post-restoration data point consistently into the direction of complete recovery toward a state that resembles natural riparian vegetation, but some research suggests that aspects of natural streams were enhanced. For example, Kuglerová et al. (2017) found higher substrate availability along enhanced-restored reaches than along channelised streams. Depending on scale, restored streams had more or equally species-rich and species-even vegetation than channelised streams (Helfield et al., 2007; Kuglerová et al., 2017), although other studies point out that riparian communities did not necessarily consist of more typical riparian species and that vegetation may need more time to recover than currently has been studied (Helfield et al., 2012; Hasselquist et al., 2015; Nilsson et al., 2017).
Channelisation of boreal streams is a consequence of human activity that mainly, although not exclusively, happened in the past. Riparian vegetation is affected in stream segments that are still channelised, and seems to be recovering in streams that have been restored. Consistent, long-term monitoring is needed to increase understanding of the recovery process but, given the long recovery time, the current lack of understanding of this process should not be a reason to postpone restoration measures.

\section{The Climate Crisis}

The climate crisis, a self-inducing process caused mainly by burning of fossil fuels and deforestation, entails increased global warming, rising seawater levels and increasingly frequently occurring extreme weather events (IPCC, 2014). These changes will lead to shifts in climatic zones within the next century (Beck et al., 2018). Temperatures in northern Scandinavia, an area now classified as boreal in the Köppen-Geiger classification, will increase and result in less snowfall but more rain, and net higher precipitation (Hoegh-Guldberg et al., 2018). The shorter freezing periods will lead to an earlier spring flood with reduced amplitude and duration, and higher discharge during autumn and winter (Andréasson et al., 2004; Woo et al., 2008), effects that are not unlike those of hydropower regulation (Arheimer et al., 2017). Interactions between the changed timing of floods, rising seawater levels and fluctuations therein may further change the flooding regime (Kasvi et al., 2019). In general, discharge is projected to increase on the catchment scale (Palmer et al., 2008). Whilst all these changes concern the entire boreal region, the magnitude of their effects on the hydrological regime differs on the regional and local scale (Andréasson et al., 2004; Teutschbein et al., 2015).

The reduced seasonal variation in discharge will cause a narrowing of the riparian zone, which leaves less space for riparian species and enables the vegetation zones above and below the riparian vegetation to encroach river banks (Figure 3; 
Nilsson et al., 2013; Jansson et al., 2019). Lower spring floods cause upland vegetation to expand and take over the upper parts of the riparian zone while higher autumn and winter flows enable aquatic and amphibious vegetation to do the same at the lower parts (Ström et al., 2011). Ström et al. (2012) describe that pattern in more detail, predicting that riparian forest and shrubs decrease in area, that graminoid vegetation shifts upward and that amphibious vegetation expands. There will be large differences in the severity of these effects between riparian species (Jansson et al., 2019). Some species will be affected but their occurrence in other than riparian habitat types may prevent population collapses and local extinction in the nearest future. In contrast, exclusively riparian species that are sensitive to changes in discharge are in more immediate danger, hence the predicted decrease of species richness of riparian vegetation (Nilsson et al., 2013).

All species in the riparian zone are subject to the other immediate consequences of a changed climate, such as altered snow cover duration, groundwater tables or evapotranspiration rates (Figure 3; Nilsson et al., 2013). Since these changes do not occur evenly throughout the year and will lead to species-specific responses, they will change riparian vegetation composition (Sarneel et al., 2019b). Shifting species-specific life histories and shifting biotic and abiotic regimes can occur in the same direction and at similar paces, but also in different directions and with different speeds. Non-matching shifts can lead to mismatches, or asynchrony, such as those reported for germination of riparian species and changed hydrological regimes (Greet et al., 2011). Thus, these mismatches may interfere with key processes of vegetation development, such as dispersal, germination, growth and survival, and reproduction. Abiotic shifts may for example concern resource availability (Perry et al., 2020) or hydrological processes (Stella et al., 2006; Balke and Nilsson, 2019). Because different species are affected in different ways, riparian vegetation composition is likely to change in the future. Although changes can be predicted for some species (e.g., Balke and Nilsson, 2019; Perry et al., 2020), the effects of extreme events, interactions between species, large local variation and interactions with other pressures make it difficult to predict what future riparian zones will look like, but decreased taxonomic and functional diversity are to be expected (Nilsson et al., 2013; Baattrup-Pedersen et al., 2018).

A process that may counteract this diversity decline in the near future is the expected increase in ice dynamics (Figure 3). Despite the shorter winter season, northern boreal streams will go through the cycle of freezing and thawing more often because of higher winter temperatures (Andréasson et al., 2004; Lind and Nilsson, 2015). High ratios of frazil and anchor ice formation are related to species-rich riparian vegetation (Engström et al., 2011). The winter flooding and scouring of ice in the riparian zone create new patches for succession to start over (Lind et al., 2014a). In the long term, however, global warming will decrease ice formation to such an extent that ice dynamics will decrease, as will their positive effect on native species diversity in riparian zones (Lind et al., 2014b; Lind and Nilsson, 2015).

Interactions with other pressures can be a double-edged sword. While streams that are already deteriorated, for example because of hydropower, may be more sensitive to the negative effects of climatic change (Palmer et al., 2008), the consequences of the climate crisis can lead to increased potential for hydropower (Graham et al., 2007; Renöfält et al., 2010). There may also be possibilities for usage of hydropower infrastructure to mitigate the effects of climate change (Arheimer et al., 2017) by mimicking natural flow regimes. Other authors conclude that the ways in which hydropower infrastructure and climate change may interact are potentially dangerous to their surroundings and can have adverse ecological effects, especially in a context of extreme events (Palmer et al., 2008; Lejon et al., 2009). We illustrate the potential effects of simultaneously occurring pressures such as flow regulation for hydropower purposes and climatic change on one specific example, the riparian soil water table, in Box 1. Hydropower infrastructure is known to limit dispersal and migration, which enables climate-related shifts in species distributions, that usually take place toward colder, upstream regions (Nilsson et al., 2005). To our knowledge, there is no research that describes the effect that such infrastructure or channelisation has on the upstream dispersal of riparian plants, but Fink and Scheidegger (2021) show that connectivity along rivers is vital for riparian species to be able to disperse to future suitable habitats.

The climatic changes expected to occur in the boreal region (Beck et al., 2018) imply that the environmental filter (sensu Catford and Jansson, 2014), which currently hampers the establishment of non-native species, may shift. More specifically, higher temperatures may facilitate populations of already existing non-native species to expand or new populations to establish, and the corridor function of riparian zones can eventually cause further spread into upland habitats (Nilsson et al., 2013). The same authors do not expect this to lead to an immediate loss of native species, although increased competition can lead to changes in species composition. While the riparian zone as a whole is vulnerable to invasions (Rose and Hermanutz, 2004), the middle parts of reaches seem most susceptible (Renöfält et al., 2005) and may thus show the effects of changed climatic filtering first. Another process affecting the potential success of non-native species is the expected increase in ice dynamics (Lind et al., 2014b) that will initially take place. Increasing ice dynamics may offer more opportunity for non-native species to establish in the area, potentially leading to displacement of native species. This eventual effect will decrease with time, as the increasing temperatures will stop the water from freezing all together.

Neither the expected changes in the separate and interacting pressures over time nor their combined effects are sufficiently quantified to make reliable predictions on how riparian vegetation will change on the local, regional or global scale. Although several studies cited here (e.g., Lind and Nilsson, 2015; Baattrup-Pedersen et al., 2018; Sarneel et al., 2019b) cover multiple years, short-term changes found in such work cannot always be extrapolated to the medium or long term (see for example Blume-Werry et al., 2016). Much recent and valuable research aims to predict climatic changes (e.g., Arheimer et al., 2017) and the effects these may have on riparian vegetation, using qualitative (Catford et al., 2013) or quantitative models (Ström et al., 2012; Jansson et al., 2019). Much of this 
work, however, focusses on the general trends of increasing temperature and changing precipitation regimes. Extreme events, such as extreme floods, droughts or wind, are often overlooked (Figure 3; Walsh et al., 2020) but will occur more frequently with increasing climatic change (e.g., Beniston et al., 2007) and are thought to impact already disturbed catchments more than non-regulated catchments (Palmer et al., 2008). According to Van Oorschot et al. (2018), extreme events that result in higher discharge, can lead to a shift of riparian vegetation toward upland in temperate ecosystems. On the other hand, their "drying scenario" suggests a shift of the riparian belt toward the stream. Bjerke et al. (2017) show that extreme events can have profound effects on boreal vegetation in general, and Nilsson et al. (2015b) predict direct and indirect negative effects on riparian vegetation.

Despite the uncertainties regarding the exact magnitude of climatic change, the pace with which it takes place and what role extreme events will come to play, the literature (e.g., Nilsson et al., 2013; Lind et al., 2014b) points out that these changes will be reflected in riparian vegetation. Theoretical models and empirical evidence consistently point out that riparian species composition, and thus the functioning of riparian ecosystems, will change (e.g., Ström et al., 2012; Baattrup-Pedersen et al., 2018). Much remains unknown about how different pressures interact with each other, especially when it comes to pressures that operate on different scales. Future research and management should focus on combining knowledge on global, regional and local processes to tailor measures for specific areas.

\section{Forestry}

Large parts of the boreal zone are covered with coniferous forest, which is one of the densest forest types in the world (Crowther et al., 2015). This makes the parts that are within reasonable distance from society interesting from an economical point of view. Indeed, forestry has become the dominant human land use in the Scandinavian (see for example Östlund et al. (1997), who describe the Swedish case) and North American (Wells et al., 2020) parts of the boreal zone, and it is an important industry in Russia as well (Leskinen et al., 2020). Forestry has replaced fire as the dominant disturbance regime in the upland habitat. Riparian vegetation, little affected by fires because of its proximity to water, may harbour trees that are relatively older than in the upland habitat, which makes them of higher interest for forestry (Timoney et al., 1997). Forestry has thus become an important activity in both upland habitat and in the riparian zones, but forestry practices and management of streams within forestry areas are different in different countries, have changed over time, and will continue to do so (see for example Lazdinis and Angelstam, 2005). At the same time, forestry consists of many different phases that each have different effects on riparian zones (Kuglerová et al., 2021). Its consequences are thus quite variable in time and space, and we will focus on the local effects of logging in the riparian zone and in upland habitat.

Logging in riparian zones leads to direct and indirect changes in vegetation composition, that occur both immediately and on longer time scales. With regard to the former, direct and immediate changes occur because of the removal of trees, which have been growing there for decades or even centuries (Figure 3). Target species such as Larix spp., Picea spp. and Pinus spp. will make up a smaller part of the plant community immediately, as adult trees will be harvested (Timoney et al., 1997). Logging also affects the understory vegetation, for example as a consequence of a changed microclimate following increased wind and sun exposure (Figure 3; Chen et al., 1995; Berrigan et al., 2021). In addition to that, the planting of species that are interesting from an industrial perspective may lead to non-native tree species becoming invasive (Richardson and Rejmánek, 2004; Marinich and Powell, 2017). These can outcompete native species or change the microhabitat. Other potential drivers of change are decreased evapotranspiration, leading to a higher water table and higher surface temperatures and, thus, altered nutrient cycling (Foley et al., 2003; Luke et al., 2007). MacDonald et al. (2014) found that this does not necessarily lead to major shifts in riparian understory composition, although the limited duration of their study makes it difficult to predict medium- and longterm effects. They did find that species turnover can be high and that the perceived resistance to change probably relies on high nutrient availability and the natural flow regime. Such changed circumstances can favour certain species, such as ruderal, shadeintolerant and generalist species along headwater streams (Newaz et al., 2019), over others. These effects may be stronger along streams of which both sides are logged and along larger streams, where there are no other trees to provide shading.

While riparian buffers can come in many forms, which also brings different functionality (Kuglerová et al., 2020; Sonesson et al., 2020), all types of buffering imply some sort of limit to harvesting in the riparian zone. Limited logging and insufficient buffer width can still lead to changes in microclimatic conditions (Jyväsjärvi et al., 2020; Berrigan et al., 2021), which means that vegetation can also change in buffers. Indeed, Oldén et al. (2019) found changes in riparian vegetation composition even in buffers in which no logging took place, although they did not find significant shifts for individual species. Contrastingly, Mallik et al. (2013) found no shifts in vegetation composition, but detected morphological changes in understory vegetation. These changes likely have to do with edge effects and emphasise the importance of location-tailored buffering rather than fixed widths (Kuglerová et al., 2014a). Poorly designed buffers also lead to rates of wind throw that are higher than natural wind throw rates (Mäenpää et al., 2020) and can cause even more bank erosion than in clear-cuts (Hylander et al., 2005), probably leading to increased degradation of riparian vegetation where the intention was to preserve it.

Changes in riparian vegetation composition following logging can occur faster or be more pronounced in combination with other pressures. For example, Newaz et al. (2019) found that forestry activities themselves led to increases in ruderal species. Open canopies, one of the consequences of logging, have been related to the presence of non-native plant species elsewhere, meaning that forestry may facilitate spread of nonnative species in riparian zones (Warren et al., 2015). Climatic change increases the possibility of non-native species invading an area as well and may lead to more non-native species becoming invasive in the riparian zone (Rose and Hermanutz, 2004). 
Another consequence of a changed climate, combined with the homogeneous character of forests that are managed for industrial purposes, is that these forests become more susceptible to pests (Folke et al., 2004) and fires (Stine et al., 2014; Hessburg et al., 2019) which can also affect riparian vegetation. The climate crisis is expected to cause earlier starts of the fire season (Stocks et al., 1998), higher fire intensity and larger fire areas (Dale et al., 2001). Kilpeläinen et al. (2010) calculated an expected 20\% increase in the annual frequency of forest fires in Finland by the end of this century alone. Even if pests or fires occur in upland habitat (Figure 5) and not in the riparian zone itself, they will lead to organisms or species from the upland habitat seeking refuge in the riparian zone, thereby exerting pressure on its vegetation composition (Tolkkinen et al., 2020).

Most forestry activities affect small streams that are not regulated for hydropower or timber floating purposes, although they may be channelised and ditched for drainage purposes (Hasselquist et al., 2021). Whenever flow regulation and forestry do occur in the same area, the hypothesis that a natural flow regime supports the resistance of riparian vegetation against negative effects of forestry (MacDonald et al., 2014) implies that riparian vegetation will undergo significant changes, as will its functioning. One function that may be altered by forestry, is the riparian zone's nutrient and pollutant retention function. While forestry itself does not lead to extra production or deposition of pollutants, it can lead to increased mobilisation of elements such as mercury. These would otherwise remain retained in the riparian zone after having been emitted or deposited from other sources (Bishop et al., 2009; Ledesma et al., 2018). Most literature describes increased mercury concentrations in the stream water (Eklöf et al., 2012) and stream biota (Lindqvist et al., 1991), and information on its effects on vegetation is scarce. While uptake of mercury via plant roots seems limited (Lindqvist et al., 1991), some trace metals may be toxic to certain riparian plants (Tolkkinen et al., 2020) and can limit their growth (Påhlsson, 1989). Other chemicals, such as pentachlorophenol that was used to treat timber (Naturvårdsverket, 2009), metals released from forest roads (Kuglerová et al., 2021) or pesticides, can also have negative effects on vegetation (Ranjan et al., 2021).

The effects of forestry on boreal riparian vegetation are understudied when compared to the scale on which forestry takes place. The focus of most research has been on the effects of logging on in-stream factors such as stream temperature and invertebrate communities via riparian zones, i.e., on their functions rather than their composition (e.g., Gundersen et al., 2010; Kuglerová et al., 2014a). There seems to be relatively little research dedicated to the direct and indirect effects of logging practice on riparian vegetation, although some work has been done since this gap was recognised by MacDonald et al. (2014). While changes in riparian microclimate seem consistent, the patterns in vegetation development are not, if found at all. This may have to do with the time-scale on which studies have taken place so far, which is merely a fraction of the forestry cycle, and with the variety of forestry practices, which is reflected in the research done on it.

\section{Land Use Change}

Land use changes, such as mining, agriculture, aquaculture and urbanisation, are major drivers of degradation of riparian ecosystems worldwide (Naiman et al., 2005). In this section, we explore some of the threats that are less described in the literature, but potentially significant in the boreal zone. The geological composition of this area makes many of its terrestrial parts interesting for mining of minerals. While we will not go into detail in the different types of mines, it is worth mentioning that their normal activity and their proneness for accidental leakages make them a risk for the local and regional environment. The surroundings of mines have different water chemistry and more polluted sediments (Leppänen et al., 2017), higher concentrations of pollutants in riparian soil (SaintLaurent et al., 2010) and accumulation of pollutants in the riparian food web (Gerson et al., 2020) in comparison with sites distant from mines. Riparian soils, moss and vegetation around mines can contain high concentrations of pollutants, even after the mine has been terminated (Qiu et al., 2005, but see Bailey et al., 2002). Pollutants, for example in the form of heavy metals (Påhlsson, 1989), can limit plant growth, and damage to vegetation in environments where multiple pollutants co-occur may be even larger than expected based on individually measured concentrations of pollutants (Schipper et al., 2011). Most work in this field, however, is on the potential for phytoremediation rather than the specific effects of mining on boreal riparian vegetation composition. One study describes the abundance of plant species such as Salix spp., Carex nigra, C. rostrata, and C. vesicaria, and the overall species richness and composition in relation to metal concentrations and finds that species composition at the three tested sites related more to local topography than metal concentrations (Husson et al., 2014). Next to the potential toxic effects of mining, its activities often cause changes in the topography and geomorphology of an area, thus reshaping surfaces or sedimentation patterns (Figure 3; Naiman et al., 2005). It is therefore very unlikely that mining, through pollution or through changing ecological processes, would have no adverse effects on riparian vegetation on the local and the regional scale.

Agriculture and aquaculture are considered major drivers for plant extinctions (Lughadha et al., 2020), and while riparian zones are among the habitats most likely subject to land use change, the authors specify that not all riparian zones are impacted equally. Although riparian zones are the most favourable areas for agriculture in boreal ecosystems, their relative remoteness and climatological limitations suggests that boreal riparian vegetation as a whole suffers relatively little from this type of land use on a regional scale (Grizzetti et al., 2017). However, wherever agriculture takes place, removal of the vegetation through land cultivation or grazing leads to direct local destruction of the vegetation. Next to that, accompanying activities such as ditching (Nybø et al., 2012; Jacks, 2019) and use of pesticides and fertilisers can cause long-term changes in hydrology (Ledesma et al., 2018) and water chemistry (Sponseller et al., 2014) and, thus, severely affect the local and regional riparian vegetation (Figure 3; Lind et al., 2019). Some of these effects resemble the potential 


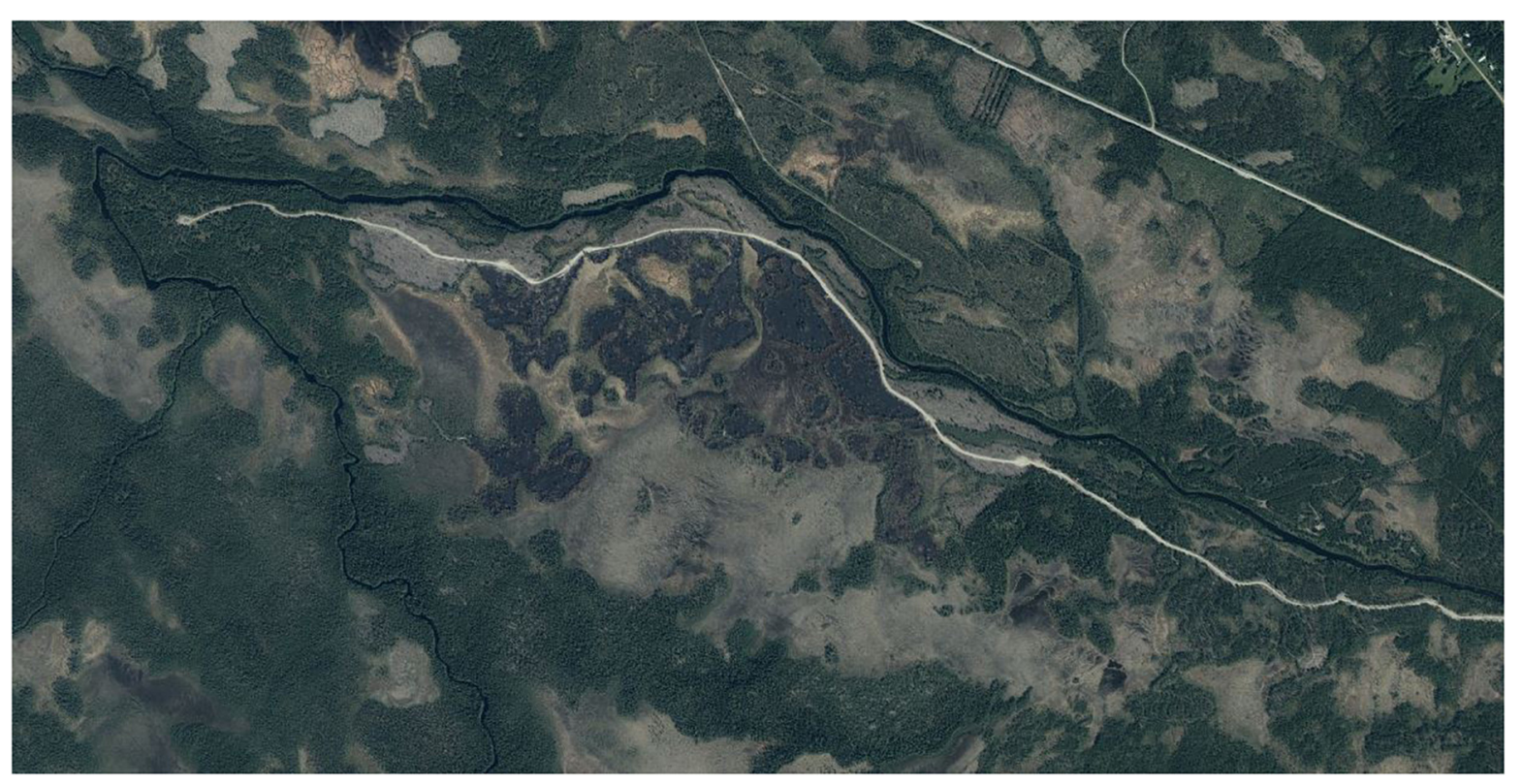

FIGURE 5 | Burnt forest patches after the 2018 forest fires on the right bank of Örån, west of Björkberg, Lycksele municipality, Sweden. CLantmäteriet.

consequences of aquaculture (Ahmed and Thompson, 2019) but, to our knowledge, this industry is far less widespread in boreal aquatic ecosystems. Under current circumstances, agriculture causes local, direct and indirect damage to boreal riparian zones and their vegetation, while regional, pollution-related damage is limited and global consequences pale in comparison to other pressures.

Urbanisation is a major pressure on riparian ecosystems all over the world (Naiman et al., 2005; Gurnell et al., 2007). While the degree of urbanisation in the boreal countries has increased and is likely to continue to increase (United Nations Department of Economic and Social Affairs Population Division, 2018, but see Boverket, 2019), the boreal zone is one of the least populated land areas on Earth (Center for International Earth Science Information Network [CIESIN], 2018) and the degree of urbanisation is thus relatively low (Figure 6). We can distinguish between direct effects of urbanisation on riparian vegetation, through the clearing of riparian zones (Walsh et al., 2005; Wheeler et al., 2005), and indirect effects, through processes that form the riparian zone (Figure 3). For example, an increase of hard surface area leads to a decrease in soil permeability, which is likely to change the flow regime in the form of more extreme high flows (Arheimer and Lindström, 2019), a mechanism that is probably similar in boreal ecosystems. Urbanisation is also known to lead to lower groundwater tables, which are the most likely cause for different riparian species composition (Groffman et al., 2003), and run-off that is richer in nutrients than in nonurban areas (Sponseller et al., 2014). Next to that, polluted run-off from urban spaces can be problematic for aquatic and riparian life, but seems limited in countries such as Sweden and Finland (Grizzetti et al., 2017). Changed hydrology in urban riparian zones may lead to higher proportions of non-native species, at a cost of riparian plant diversity (Burton et al., 2005). To our knowledge, however, there is no information on the expected effects of increasing urbanisation on riparian vegetation in boreal ecosystems, and the challenges in this specific field of research are manifold (Nilsson et al., 2003). While large parts of the boreal zone are still not accessed or inaccessible (Leskinen et al., 2020), the effects of urbanisation on riparian vegetation can be profound (e.g., Décamps et al., 1988; Aguiar and Ferreira, 2005) and may thus increase in the future.

Increased human inhabitation of an area leads to more infrastructure and exurban activities, such as recreation by the area's inhabitants and tourists. More and more intensively used infrastructure can lead to pollution in riparian zones, for example through the use of road salt, which can affect plant growth (Stoler et al., 2018). Recreation can be non-consumptive and consumptive (Naiman et al., 2005; Schafft et al., 2021), the former including activities such as camping and photography, and the latter fishing and firewood cutting (Poff et al., 2011). All of these activities imply some kind of access which may lead to trampling of herbs and damage to seedlings or young shrubs and trees, which can advantage disturbance-adapted species (Manning, 1979). Trampling, which has been studied in alpine and northern ecosystems, may have negative effects on vegetation cover (Monz, 2002) and the abundance and richness of plants (Jägerbrand and Alatalo, 2015). Although some communities will recover from light to moderate levels of trampling (Monz, 2002), other communities may take decades to regenerate after severe trampling (Willard et al., 2007). Next to that, diseases or nonnative species can be introduced to an area, and consumptive activities may lead to decreases of specific species (groups) (Poff et al., 2011). While none of these activities and their effects are described for boreal riparian ecosystems, the way they are for 


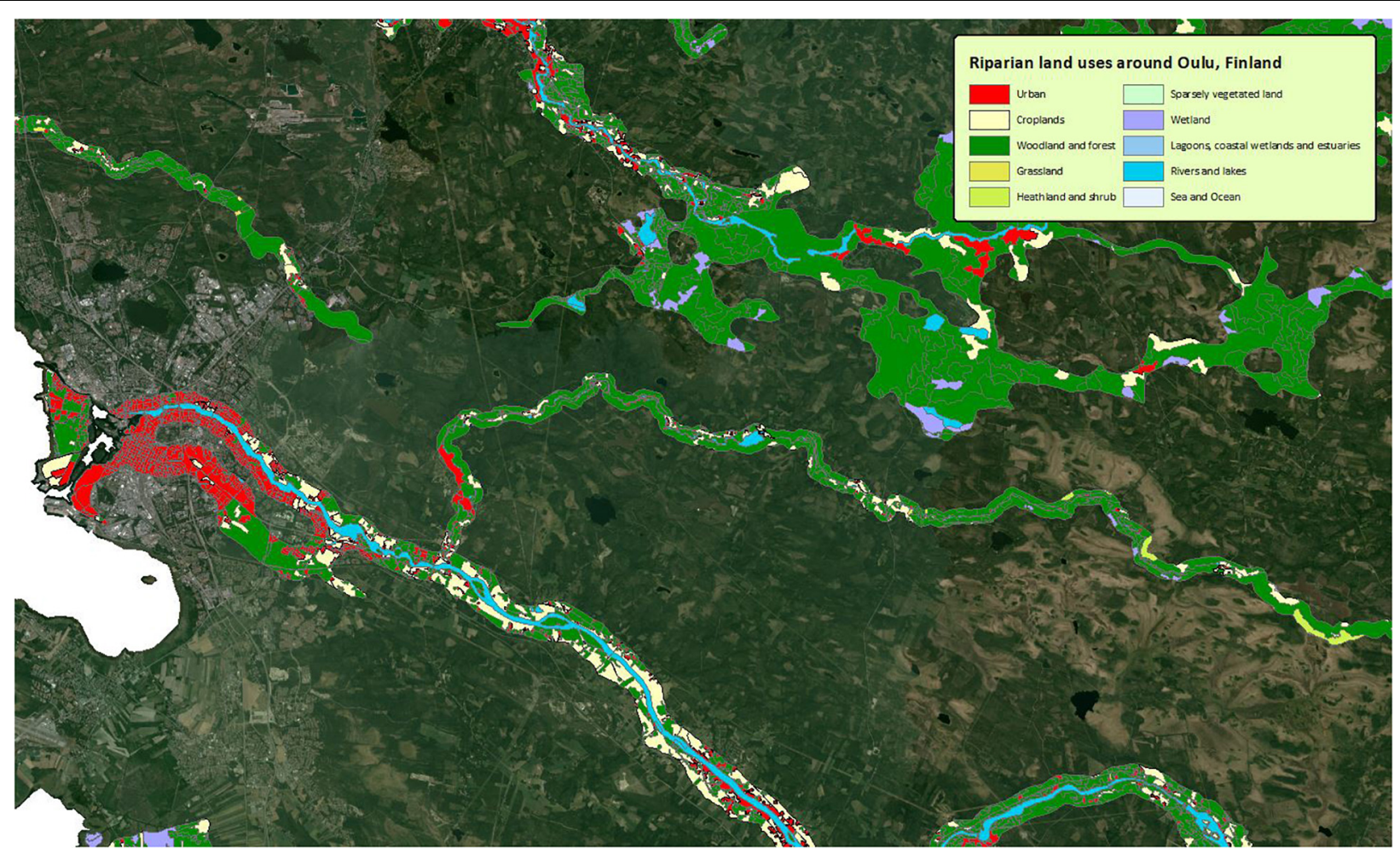

FIGURE 6 | Riparian land uses in the surroundings of Oulu, Finland. Based on the Copernicus Land Cover/Land Use classification (Forslund, 2012) and the VHR2018 dataset from the European Environmental Agency. (OOpenStreetMap, and the GIS user community.

other areas (e.g., Madej et al., 1994), their damaging mechanisms are most likely the same (Figure 3). Reachability of locations is a prerequisite for recreations to take place, and pressure by recreation is thus probably more common in Scandinavia than in Russia or North America. Moreover, recreational activities usually take place along larger stream orders (Riis et al., 2020; Arif et al., 2021), which means that they do not affect headwaters and low-order streams that represent the largest part of the catchment and thus do relatively little damage to riparian vegetation on the regional and global scale.

\section{Non-native Species}

Riparian zones are thought to be sensitive to invasions by nonnative species because of their direct connection to aquatic ecosystems (e.g., Nilsson et al., 2010), relatively intensive anthropogenic usage (e.g., Richardson et al., 2007) and because of their instable, disturbance-prone character (e.g., Naiman et al., 2005). The natural disturbance regime, consisting of processes such as ice-scouring or flooding events, make riparian zones relatively patchy and open for secondary succession and, thus, for the establishment of new individuals and new species. Not all non-native species become invasive, and factors such as the type of disturbance (Jauni et al., 2015, but see Ström et al., 2014), species characteristics (Ni et al., 2021) and a system's invasibility (Lonsdale, 1999) codetermine the effects a species may have on an ecosystem. Here, we follow the definition of Mack et al. (2000) and define invasive non-native species as species that invade a new area in which they establish and form a threat to the abiotic or biotic environment.

Invasion and spread of non-native plant species occurs in riparian zones worldwide (e.g., Planty-Tabacchi et al., 1996; Rose and Hermanutz, 2004; Hejda and Pyšek, 2006; Ronzhina, 2020). While riparian vegetation in northern Scandinavia is usually described as primarily native (Nilsson, 1999 as cited in Ström et al., 2011), this is in stark contrast with findings in other boreal regions (e.g., in North America) where Dynesius et al. (2004) reported up to $9 \%$ non-native species in riparian plant communities. Boreal riparian zones are usually lowcompetition ecosystems, which is why non-native plants may be able to outcompete native species, and lead to significant shifts in vegetation composition (Figure 7). Common traits of invasive species, such as high biomass production, large stature, nitrogen fixation or high transpiration rates, may in turn change community structure, such as vertical biomass distribution, suppress processes such as germination, and affect ecosystem fluxes and functions, such as soil $\mathrm{N}$ or water availability (Figure 3; Akamatsu et al., 2011; Simberloff, 2011; Ruwanza et al., 2013; Catford and Jansson, 2014). In addition, non-native invertebrates, fungi and micro-organisms can become pests, parasites or pathogens and damage native vegetation as such (Kominoski et al., 2013; Lapin et al., 2021).

Non-native species do already occur in Scandinavian boreal riparian zones, but are not considered invasive (Dynesius et al., 2004; Nilsson et al., 2013). Certain types of 


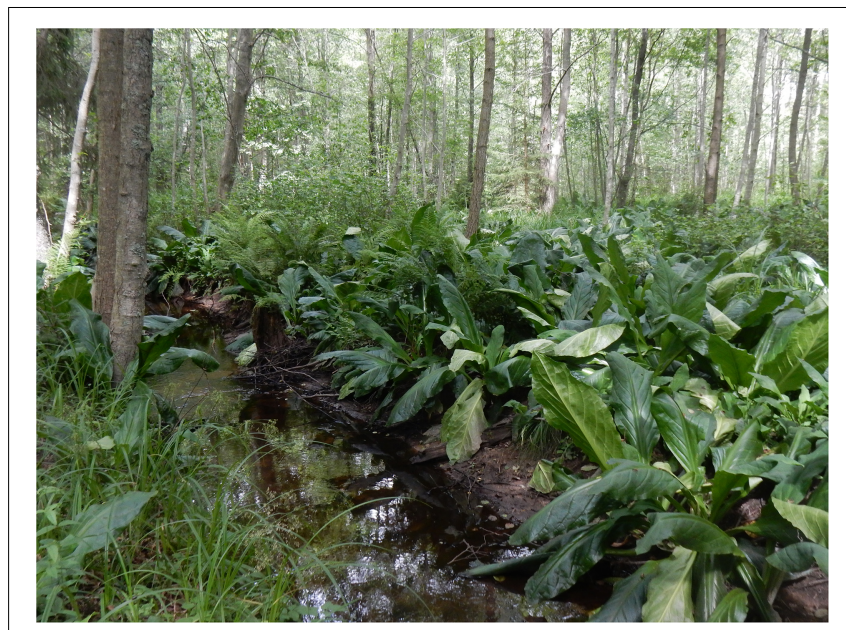

FIGURE 7 | American Skunk-cabbage (Lysichiton americanus) along Klokkarhyttebäcken, Sweden. Photo by Owe Nilsson.

land and water use are considered a catalyst for the establishment of non-native species. Hydropower is the most important of such land uses in the boreal area, as it causes an increase of bare patches or creates new habitat by changing the flow regime and may thus enable non-native species to establish (Tickner et al., 2001; Bejarano et al., 2020b). Even species planted for forestry purposes can be considered invasive when they are planted in, or spread into, riparian zones (Richardson and Rejmánek, 2004; Kominoski et al., 2013). The relatively limited character of other human activities, resulting in low propagule pressure (Keller et al., 2011), may be a reason for the relatively minor problems with non-native species in boreal zones as compared with agricultural landscapes in Central Europe with the highest proportions of established species. Future changes, such as increased climatic change in combination with human activity, may however, increase the risk of further disruption of native riparian plant communities. Predictions on risks of establishment of terrestrial species show that large parts of boreal Scandinavia are under medium to high risk during the $21^{\text {st }}$ century, and boreal North America and Russia under low to high risk (Early et al., 2016), but it is unclear in how far these projections can be used for aquatic species. Although projections of climatic change are not equal across the entire Scandinavian boreal zone, the generally higher winter temperatures and increased annual precipitation will support a different type of vegetation than has been found during the past centuries (Nilsson et al., 2013). Other changes in the hydrological regime, such as a lower and earlier spring flood, will decrease the extent and change vegetation composition of the riparian zone (Ström et al., 2012). While a lower spring flood may mean that lower numbers of non-native plant propagules are deposited on the riverbanks, we expect that the narrowing of the riparian zone can also lower the input of native plant propagules. The expected climatic changes will enable new species to disperse into the area, adventive species to establish actual populations and newly established populations to spread locally and fill distribution gaps. This can lead to non-native plant species becoming invasive in boreal riparian zones, and thus changing their composition and functioning.

Already degraded riparian vegetation is likely more vulnerable to the competitive capacities of non-native species than undisturbed riparian vegetation (Rose and Hermanutz, 2004; Zelnik et al., 2015; Pattison et al., 2017). Established populations of invasive non-native species in the riparian zone may also present a risk for the surrounding landscape. While this may be an unsuitable matrix for species spread in itself, it may be prone to penetration by non-native species through increased propagule pressure from the riparian zone (Richardson et al., 2007). Another, yet to be explored facet of riparian connectivity is the effect that restoration of hydropower-regulation may have on riparian vegetation. Restoration measures, such as the (partial) removal of dams, have the potential to increase the risk of spread of non-native plant species, especially around reservoirs (Shafroth et al., 2002; Tullos et al., 2016). Studies from temperate regions show that these problems may be small (Lisius et al., 2018; Ravot et al., 2020), but we do not know of examples from the boreal region.

\section{SYNTHESIS}

Each of the anthropogenic pressures described in the sections above affects boreal riparian vegetation or parts of it through one or more biotic or abiotic ecosystem processes. We have visualised the pressures in a conceptual model, subdivided in components (smaller circles, such as "temperature," "precipitation," and "extreme events" as components of the climate crisis) if these can have different effects (Figure 3).

The model indicates the effects of these pressures on different parts of the ecosystem and ecological processes that build the vegetation community and constitute a plant's life cycle. The flow regime, the major driver behind riparian dynamics (Lytle and Poff, 2004), is affected widely but not everywhere, through adaptations for hydropower (Palmer et al., 2008), and globally as a consequence of the climate crisis (Nilsson et al., 2013). The application of hydropower leads to direct destruction of riparian zones and undermines many of the processes that riparian vegetation depends on in the long term. On the other hand, anthropogenic climatic change is a process that is only just beginning, but expected to become more extreme in the future (Arheimer et al., 2017). Forestry and other land uses can have profound direct effects locally and on the short term, for example when riparian vegetation is removed. They also have more regional, indirect and long-term effects such as pollution of water, increased insolation that damages shadetolerant understory species, and wind throw in poorly designed buffer zones (Lind et al., 2019; Kuglerová et al., 2021). In the past, forestry and channelisation for transport of timber, have led to more negative effects in riparian zones than other land uses. Even if other types of land uses become more widespread, it is likely that forestry practice in its current form will stay the main land use damaging riparian vegetation. Other land uses are, together 
with climatic change, the main drivers for the spread of nonnative species into boreal riparian zones and may lead to a level of competition where native riparian plant species get outcompeted (Dynesius et al., 2004).

While many of these changes can affect all species to some extent, e.g., when non-native species take up physical space at the cost of native species or when all riparian vegetation is removed for the placement of a dam, it is also possible to identify groups that are affected more than others. Such specific responses are described at the respective pressures that are found to cause them. Recognising where a pressure or a set of pressures can affect ecological processes or characteristics can open the door to more appropriate research questions and more adequate management. We illustrate the complex web of interactions between effects of multiple pressures on a single factor or process with one example, the riparian soil water table, in Figure 8 and Box 1.

\section{DISCUSSION}

Our conceptual model brings together a wide range of anthropogenic pressures and their effects on riparian vegetation. With the knowledge currently available and the complex and variable way in which the pressures interact, quantifying their effects remains difficult for the foreseeable future. Simultaneously occurring pressures in an ecosystem, already difficult to quantify when considered separately, can have effects that counteract each other, work in an additive or even synergistic way or cause systems to cross thresholds relatively unexpectedly (Stella and Bendix, 2019). Another difficulty is that most research that is available to the English-speaking community comes from Sweden and, to a lesser extent, from Finland and English-speaking Canada, and may not be directly applicable in Norway or Russia. The complexity of the effects of pressures makes timely research

BOX 1 | Flow regulation for hydropower limits the amount of water that riparian soils take up during spring by decreasing the spring flood (Figure 8). Simultaneously, the climate crisis changes soil moisture through altered temperature patterns, which cause different evapotranspiration rates. In addition, forestry can lead to larger canopy gaps that cause more evapotranspiration, or forestry or agricultural ditches can increase discharge to the extent that water disappears from the riparian soil. These effects will change the riparian soil water table during at least some months of the year and at least in parts of the catchment, although changed precipitation patterns as another aspect of the climate crisis can counteract them to some extent.

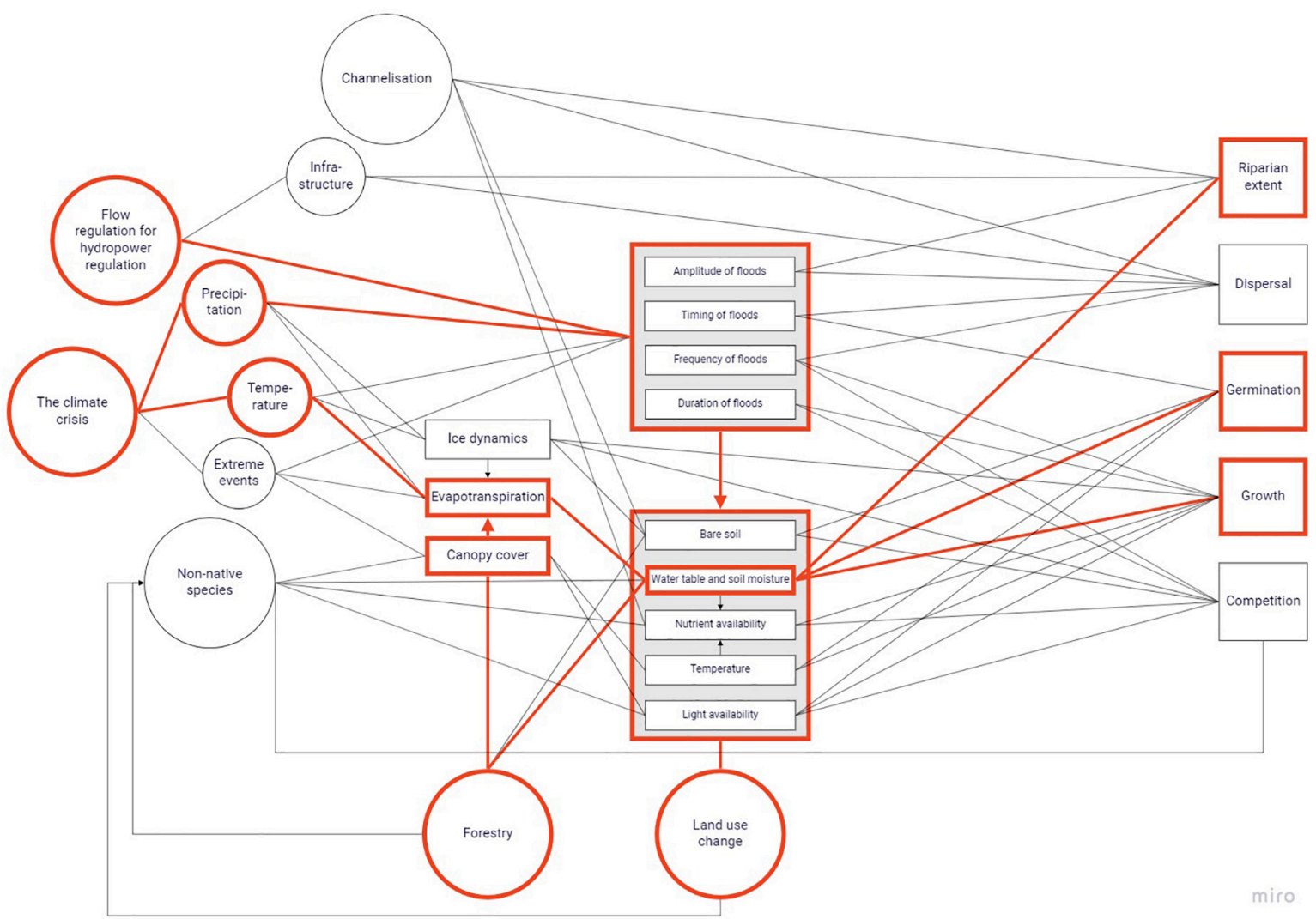

FIGURE 8 | An example of application of the conceptual model on the riparian soil water table. Pressures and processes that affect or are affected by the soil water table are marked in red.

The soil water table then codetermines the extent to which plants successfully germinate and grow, in a riparian zone of which it also codetermines the extent (Figure 8). Not all species or species groups react to these changes in a similar manner, and in this example riparian or flooding-tolerant species that are drought-sensitive or demand shading, may experience reduced germination success and growth, and may eventually be outcompeted by ruderal or shading-intolerant species. 
on relevant spatial scales more important than ever, especially in understudied areas.

In this review, we show that pressures occur simultaneously on local, regional and global scales. Their effects are not the same across these scales, and are not necessarily similar within scales, when measured at different locations or different times. This added variation is caused by interactions with the local and regional environment (Bendix, 1994; Polvi et al., 2020). Legacies from past disturbances can also change how riparian vegetation develops (Sarneel et al., 2019a; Janssen et al., 2020), and makes that effects found in one catchment cannot always be extrapolated in space or time. This emphasises the importance of increasing the understanding of local and regional hydrogeomorphology and past disturbances in an area.

Understanding the history of an area can also help delimit an appropriate time scale for research and restoration plans. There are many practical, financial and, eventually, political factors that limit the possibilities of collecting data over a longer period of time (Courchamp et al., 2015). That complicates the correct interpretation of some changes, for example, when comparing the effects of competition, which may be more pronounced on the short term, while other processes, such as dispersal, may only be measurable on a long-term scale. Inertia thus complicates ecological research, and puts another emphasis on the importance of longterm research efforts (Turner and Gardner, 2015). And while rare examples of "ecosystem experiments" do occur (Stella and Bendix, 2019), researchers do not always get the opportunity to conduct control measurements before a pressure-exerting activity starts. Intensifying collaborations between managers and researchers is as mutual a responsibility as it will be helpful to the advancement of the field. Studies such as those of Pickett (1989) and Nilsson et al. (2015a) acknowledge the difficulties with measuring control sites, or groups, in ecology and the need for more longterm research.

Another challenge is the identification of the right response variable. Both from a functional and from a conservation point of view, knowing which species will be affected can be more valuable than knowing that species will be affected. While our analysis includes species and groups that are very likely to react to anthropogenic pressures, it is difficult to be more specific. Not many studies have focussed on specific species or groups in the past, although there is a shift in recent years (see for example Baattrup-Pedersen et al., 2018 and Bejarano et al., 2018b). In addition, species composition differs across the boreal zone and one specific species may react differently to pressures in different communities. We have therefore

\section{REFERENCES}

Aguiar, F. C., and Ferreira, M. T. (2005). Human-disturbed landscapes: effects on composition and integrity of riparian woody vegetation in the Tagus River basin, Portugal. Environ. Conserv. 32, 30-41. doi: 10.1017/S0376892905001992 Aguiar, F. C., Segurado, P., Martins, M. J., Bejarano, M. D., Nilsson, C., Portela, M. M., et al. (2018). The abundance and distribution of guilds of riparian woody plants change in response to land use and flow regulation. J. Appl. Ecol. 55, 2227-2240. doi: 10.1111/1365-2664.13110 included in the text (1) species groups specifically mentioned in the literature and (2) groups with certain physiological, phenological or ecological characteristics that most likely are affected similarly across the boreal zone. Shifting the focus beyond species identity by analysing functional response or effect traits (Truchy et al., 2015) can help increase the understanding of physical and ecological processes affecting the riparian zone and simultaneously increases the applicability of results across spatial and temporal scales.

We conclude that, while much progress has been made in the field of riparian research, the current levels of pressure call for a greater sense of urgency within the field and general governmental, scientific and societal practice. This review identifies forestry and hydropower as amply proven pressures on boreal riparian vegetation, and the literature shows that there are many ways in which involved actors can mitigate the negative effects of these industries, whereas the climate crisis calls for global action and involves a wider range of actors. Our conceptual model is also meant to function as a stepping stone for researchers and managers alike to explore mechanisms that could be relevant for their work. It will hopefully contribute to a better understanding of processes and interactions within boreal riparian ecosystems, and the way they are affected by external and internal pressures.

\section{AUTHOR CONTRIBUTIONS}

JH, LL, and RE conceived the idea for the study and designed its structure. JH wrote the first draft. LL and RE made comments and additions to the manuscript. All authors read and approved the final manuscript.

\section{FUNDING}

The authors were funded by the Department of Environmental and Life Sciences at Karlstad University. Open access was funded by Karlstad University.

\section{ACKNOWLEDGMENTS}

The authors would like to thank their colleagues from the Department of Environmental and Life Sciences, Karlstad University, for valuable input and feedback on a rudimentary version of the model. The authors would also like to thank editor $\mathrm{BK}$ and the two reviewers for their comments on the manuscript. 
Andersson, E., Nilsson, C., and Johansson, M. E. (2000b). Plant dispersal in boreal rivers and its relation to the diversity of riparian flora. J. Biogeogr. 27, 1095-1106. doi: 10.1046/j.1365-2699.2000.00481

Andréasson, J., Bergström, S., Carlsson, B., Graham, L. P., and Lindström, G. (2004). Hydrological Change - Climate Change Impact Simulations for Sweden. Ambio 33, 228-234. doi: 10.1579/0044-7447-33.4.228

Arheimer, B., Donnelly, C., and Lindström, G. (2017). Regulation of snow-fed rivers affects flow regimes more than climate change. Nat. Commun. 8:62. doi: 10.1038/s41467-017-00092-8

Arheimer, B., and Lindström, G. (2019). Detecting changes in river flow caused by wildfires, storms, urbanization, regulation, and climate across Sweden. Water Resour. Res. 55, 8990-9005. doi: 10.1029/2019WR02 4759

Arif, M., Jie, Z., Wokadala, C., Songlin, Z., Zhongxun, Y., Zhangting, C., et al. (2021). Assessing riparian zone changes under the influence of stress factors in higher-order streams and tributaries: implications for the management of massive dams and reservoirs. Sci. Total Environ. 776:146011. doi: 10.1016/j. scitotenv.2021.146011

Armstrong, W., Brandle, R., and Jackson, M. B. (1994). Mechanism of Flood Tolerance Plants. Acta Bot. Neerl. 43, 307-358. doi: 10.1111/j.1438-8677.1994. tb00756.x

Baattrup-Pedersen, A., Garssen, A., Göthe, E., Hoffmann, C. C., Oddershede, A., Riis, T., et al. (2018). Structural and functional responses of plant communities to climate change-mediated alterations in the hydrology of riparian areas in temperate Europe. Ecol. Evol. 8, 4120-4135. doi: 10.1002/ece3.3973

Bailey, E. A., Gray, J. E., and Theodorakos, P. M. (2002). Mercury in vegetation and soils at abandoned mercury mines in southwestern Alaska, USA. Geochemistry 2, 275-285. doi: 10.1144/1467-787302-032

Balke, T., and Nilsson, C. (2019). Increasing synchrony of annual river-flood peaks and growing season in Europe. Geophys. Res. Lett. 46, 10446-10453. doi: 10.1029/2019GL084612

Beck, H. E., Zimmermann, N. E., McVicar, T. R., Vergopolan, N., Berg, A., and Wood, E. F. (2018). Present and future Köppen-Geiger climate classification maps at 1-km resolution. Nat. Sci. Data 5:180214. doi: 10.1038/sdata.2018.214

Bejarano, M. D., Nilsson, C., and Aguiar, F. C. (2018b). Riparian plant guilds become simpler and most likely fewer following flow regulation. J. Appl. Ecol. 55, 365-376. doi: 10.1111/1365-2664.12949

Bejarano, M. D., Jansson, R., and Nilsson, C. (2018a). The effects of hydropeaking on riverine plants: a review. Biol. Rev. 93, 658-673. doi: 10.1111/brv.12362

Bejarano, M. D., Sarneel, J., Su, X., and Sordo-Ward, Á (2020a). Shifts in riparian plant life forms following flow regulation. Forests 11:518. doi: 10.3390/ F11050518

Bejarano, M. D., Sordo-Ward, Á, Alonso, C., Jansson, R., and Nilsson, C. (2020b). Hydropeaking affects germination and establishment of riverbank vegetation. Ecol. Appl. 30:e02076. doi: 10.1002/eap.2076

Bendix, J. (1994). Scale, direction, and pattern in riparian vegetation-environment relationships. Ann. Assoc. Am. Geogr. 84, 652-665. doi: 10.1111/j.1467-8306. 1994.tb01881.x

Beniston, M., Stephenson, D. B., Christensen, O. B., Ferro, C. A. T., Frei, C., Goyette, S., et al. (2007). Future extreme events in European climate: an exploration of regional climate model projections. Clim. Change 81, 71-95. doi: 10.1007/s10584-006-9226-z

Bennett, A. F., Nimmo, D. G., and Radford, J. Q. (2014). Riparian vegetation has disproportionate benefits for landscape-scale conservation of woodland birds in highly modified environments. J. Appl. Ecol. 51, 514-523. doi: 10.1111/13652664.12200

Berrigan, A., Halme, P., Peura, M., and Oldén, A. (2021). Are wide but selectively logged buffer strips better than narrow ones? Scand. J. For. Res. 36, 177-187. doi: 10.1080/02827581.2020.1858957

Bishop, K., Allan, C., Bringmark, L., Garcia, E., Hellsten, S., Högbom, L., et al. (2009). The effects of forestry on $\mathrm{Hg}$ bioaccumulation in nemoral/boreal waters and recommendations for good silvicultural practice. Ambio 38, 373-380. doi: 10.1579/0044-7447-38.7.373

Bjerke, J. W., Treharne, R., Vikhamar-Schuler, D., Karlsen, S. R., Ravolainen, V., Bokhorst, S., et al. (2017). Understanding the drivers of extensive plant damage in boreal and Arctic ecosystems: insights from field surveys in the aftermath of damage. Sci. Total Environ. 59, 1965-1976. doi: 10.1016/j.scitotenv.2017.05. 050
Blume-Werry, G., Kreyling, J., Laudon, H., and Milbau, A. (2016). Short-term climate change manipulation effects do not scale up to long-term legacies: effects of an absent snow cover on boreal forest plants. J. Ecol. 104, 1638-1648. doi: 10.1111/1365-2745.12636

Boverket (2019). Urbanisering. Available online at: https://www.boverket. se/sv/samhallsplanering/bostadsmarknad/bostadsforsorjning/flyttningar/ urbanisering/ (accessed October 26, 2021).

Burton, M. L., Samuelson, L. J., and Pan, S. (2005). Riparian woody plant diversity and forest structure along an urban-rural gradient. Urban Ecosyst. 8, 93-106. doi: $10.1007 / \mathrm{s} 11252-005-1421-6$

Catford, J. A., and Jansson, R. (2014). Drowned, buried and carried away: effects of plant traits on the distribution of native and alien species in riparian ecosystems. New Phytol. 204, 19-36. doi: 10.1111/nph.12951

Catford, J. A., Naiman, R. J., Chambers, L. E., Roberts, J., Douglas, M., and Davies, P. (2013). Predicting novel riparian ecosystems in a changing climate. Ecosystems 16, 382-400. doi: 10.1007/s10021-012-9566-7

Center for International Earth Science Information Network [CIESIN] (2018). Gridded Population of the World, Version 4 (GPWv4): Population Density Adjusted to Match 2015 Revision UN WPP Country Totals, Revision 11. New York, NY: NASA Socioeconomic Data and Applications Center (SEDAC), doi: $10.7927 / \mathrm{H} 4 \mathrm{~F} 47 \mathrm{M} 65$

Chen, J., Franklin, J. F., and Spies, T. A. (1995). Growing-season microclimatic gradients from clearcut edges into old-growth douglas-fir forests. Ecol. Appl. 5, 74-86. doi: 10.2307/1942053

Courchamp, F., Dunne, J. A., Le Maho, Y., May, R. M., Thébaud, C., and Hochberg, M. E. (2015). Fundamental ecology is fundamental. Trends Ecol. Evol. 30, 9-16. doi: 10.1016/j.tree.2014.11.005

Couto, T. B. A., and Olden, J. D. (2018). Global proliferation of small hydropower plants - science and policy. Front. Ecol. Environ. 16, 91-100. doi: 10.1002/fee. 1746

Crowther, T. W., Glick, H. B., Covey, K. R., Bettigole, C., Maynard, D. S., Thomas, S. M., et al. (2015). Mapping tree density at a global scale. Nature 525, 201-205. doi: $10.1038 /$ nature 14967

Dale, V. H., Joyce, L. A., McNulty, S., Neilson, R. P., Ayres, M. P., Flannigan, M. D., et al. (2001). Climate change and forest disturbances: climate change can affect forests by altering the frequency, intensity, duration, and timing of fire, drought, introduced species, insect and pathogen outbreaks, hurricanes, windstorms, ice storms, or landslides. BioScience 51, 723-734.

Décamps, H., Fortuné, M., Gazelle, F., and Pautou, G. (1988). Historical influence of man on the riparian dynamics of a fluvial landscape. Landsc. Ecol. 1, 163-173. doi: 10.1007/BF00162742

Dietrich, A. L., Nilsson, C., and Jansson, R. (2016). A phytometer study evaluating the effects of stream restoration on riparian vegetation. Ecohydrology 9, 646658. doi: 10.1002/eco.1663

Dufour, S., Rodríguez-González, P. M., and Laslier, M. (2019). Tracing the scientific trajectory of riparian vegetation studies: main topics, approaches and needs in a globally changing world. Sci. Total Environ. 653, 1168-1185. doi: 10.1016/j. scitotenv.2018.10.383

Dynesius, M., Jansson, R., Johansson, M. E., and Nilsson, C. (2004). Intercontinental similarities in riparian-plant diversity and sensitivity to river regulation. Ecol. Appl. 14, 173-191. doi: 10.1890/02-5127

Early, R., Bradley, B. A., Dukes, J. S., Lawler, J. J., Olden, J. D., Blumenthal, D. M., et al. (2016). Global threats from invasive alien species in the twentyfirst century and national response capacities. Nat. Commun. 7:12485. doi: $10.1038 /$ ncomms 12485

Eklöf, K., Kraus, A., Weyhenmeyer, G. A., Meili, M., and Bishop, K. (2012). Forestry influence by stump harvest and site preparation on methylmercury, total mercury and other stream water chemistry parameters across a boreal landscape. Ecosystems 15, 1308-1320. doi: 10.1007/s10021-0129586-3

Energimyndigheten (2020). Energibalans 2005-2018. Available online at: https://www.energimyndigheten.se/globalassets/statistik/officiell-statistik/ statistikprodukter/arlig-energibalans/ovrigt/dokumentation-och-beskrivningversion-2019_1.pdf (accessed October 30, 2020).

Englund, G., and Malmqvist, B. (1996). Effects of flow regulation, habitat area and isolation on the macroinvertebrate fauna of rapids in north Swedish rivers. Regul. Rivers 12, 433-445. doi: 10.1002/(sici)1099-1646(199607)12:4/5<433:: aid-rrr415<3.0.co;2-6 
Engström, J., Jansson, R., Nilsson, C., and Weber, C. (2011). Effects of river ice on riparian vegetation. Freshw. Biol. 56, 1095-1105. doi: 10.1111/j.1365-2427.2010. 02553.x

Fink, S., and Scheidegger, C. (2021). Changing climate requires shift from refugia to sanctuaries for floodplain forests. Landsc. Ecol. 36, 1423-1439. doi: 10.1007/ s10980-021-01224-8

Foley, J. A., Costa, M. H., Delire, C., Ramankutty, N., and Snyder, P. (2003). Green surprise? how terrestrial ecosystems could affect earth's climate. Front. Ecol. Environ. 1, 38-44. doi: 10.2307/3867963

Folke, C., Carpenter, S., Walker, B., Scheffer, M., Elmqvist, T., Gunderson, L., et al. (2004). Regime shifts, resilience, and biodiversity in ecosystem management. Ann. Rev. Ecol. Evol. Syst. 35, 557-581. doi: 10.1146/annurev.ecolsys.35.021103. 105711

Forslund, L. (2012). Riparian Zones 2012 LCLU. Denmark: European Environment Agency.

Gardeström, J., Holmqvist, D., Polvi, L. E., and Nilsson, C. (2013). Demonstration restoration measures in tributaries of the vindel river catchment. Ecol. Soc. 18:8. doi: 10.5751/ES-05609-180308

Gerson, J. R., Naslund, L. C., Liu, Y.-T., Hsu-Kim, H., Driscoll, C. T., Ross, M. R. V., et al. (2020). Mercury and selenium loading in mountaintop mining impacted alkaline streams and riparian food webs. Biogeochemistry 150, 109-122. doi: 10.1007/s10533-020-00690-7

Graham, L. P., Andréasson, J., and Carlsson, B. (2007). Assessing climate change impacts on hydrology from an ensemble of regional climate models, model scales and linking methods - A case study on the Lule River basin. Clim. Change 81, 293-307. doi: 10.1007/s10584-006-9215-2

Grant, M. J., and Booth, A. (2009). A typology of reviews: an analysis of 14 review types and associated methodologies. Health Info. Libr. J. 26, 91-108. doi: 10.1111/j.1471-1842.2009.00848.x

Greet, J., Fischer, S., and Russell, K. (2020). Longer duration flooding reduces the growth and sexual reproductive efforts of a keystone wetland tree species. Wetl. Ecol. Manage. 28, 655-666. doi: 10.1007/s11273-020-09738-9

Greet, J., Webb, J. A., and Cousens, R. D. (2011). The importance of seasonal flow timing for riparian vegetation dynamics: a systematic review using causal criteria analysis. Freshw. Biol. 56, 1231-1247. doi: 10.1111/j.1365-2427.2011. 02564.x

Grizzetti, B., Pistocchi, A., Liquete, C., Udias, A., Bouraoui, F., and Van De Bund, W. (2017). Human pressures and ecological status of European rivers. Sci. Rep. 7:205. doi: 10.1038/s41598-017-00324-3

Groffman, P. M., Bain, D. J., Band, L. E., Belt, K. T., Brush, G. S., Grove, J. M., et al. (2003). Down by the riverside: urban riparian ecology. Front. Ecol. Environ. 1, 315-321.

Gundersen, P., Laurén, A., Finér, L., Ring, E., Koivusalo, H., Sætersdal, M., et al. (2010). Environmental services provided from riparian forests in the nordic countries. Ambio 39, 555-566. doi: 10.1007/s13280-010-0073-9

Gurnell, A., Lee, M., and Souch, C. (2007). Urban rivers: hydrology, geomorphology, ecology and opportunities for change. Geogr. Compass 1, 1118-1137. doi: 10.1111/j.1749-8198.2007.00058.x

Hasselquist, E. M., Kuglerová, L., Sjögren, J., Hjältén, J., Ring, E., Sponseller, R. A., et al. (2021). Moving towards multi-layered, mixed-species forests in riparian buffers will enhance their long-term function in boreal landscapes. For. Ecol. Manage. 493:119254. doi: 10.1016/j.foreco.2021.119254

Hasselquist, E. M., Nilsson, C., Hjältén, J., Jørgensen, D., Lind, L., and Polvi, L. E. (2015). Time for recovery of riparian plants in restored northern Swedish streams: a chronosequence study. Ecol. Appl. 25, 1373-1389. doi: 10.1890/141102.1

Hauer, C., Wagner, B., Aigner, J., Holzapfel, P., Flödl, P., Liedermann, M., et al. (2018). State of the art, shortcomings and future challenges for a sustainable sediment management in hydropower: a review. Renew. Sustain. Energy Rev. 98, 40-55. doi: 10.1016/j.rser.2018.08.031

Hejda, M., and Pyšek, P. (2006). What is the impact of Impatiens glandulifera on species diversity of invaded riparian vegetation? Biol. Conserv. 132, 143-152. doi: 10.1016/j.biocon.2006.03.025

Helfield, J. M., Capon, S. J., Nilsson, C., Jansson, R., and Palm, D. (2007). Restoration of rivers used for timber floating: effects on riparian plant diversity. Ecol. Appl. 17, 840-851. doi: 10.1890/06-0343

Helfield, J. M., Engström, J., Michel, J. T., Nilsson, C., and Jansson, R. (2012). Effects of river restoration on riparian biodiversity in secondary channels of the
Pite River, Sweden. Environ. Manage. 49, 130-141. doi: 10.1007/s00267-0119773-6

Hessburg, P. F., Miller, C. L., Parks, S. A., Povak, N. A., Taylor, A. H., Higuera, P. E., et al. (2019). Climate, environment, and disturbance history govern resilience of western North American Forests. Front. Ecol. Evol. 7:239. doi: 10.3389/fevo. 2019.00239

Hoegh-Guldberg, O., Jacob, D., Taylor, M., Bindi, M., Brown, S., Camilloni, I., et al. (2018). "Impacts of $1.5^{\circ} \mathrm{C}$ global warming on natural and human systems," in Global Warming of $1.5^{\circ}$ C. An IPCC Special Report On The Impacts of Global Warming Of $1.5^{\circ} \mathrm{C}$ Above Pre-Industrial Levels And Related Global Greenhouse Gas Emission Pathways, In The Context of Strengthening The Global Response To The Threat Of Climate Change, eds V. Masson-Delmotte, P. Zhai, H.-O. Pörtner, D. Roberts, J. Skea, P. R. Shukla, et al. (Geneva: World Meteorological Organization Technical Document), 175-311.

Husson, E., Lindgren, F., and Ecke, F. (2014). Assessing biomass and metal contents in riparian vegetation along a pollution gradient using an unmanned aircraft system. Water Air Soil Pollut. 225:1957. doi: 10.1007/s11270-0141957-2

Hylander, K., Dynesius, M., Jonsson, B. G., and Nilsson, C. (2005). Substrate form determines the fate of bryophytes in riparian buffer strips. Ecol. Appl. 15, 674-688. doi: 10.1890/04-0570

IPCC (2014). “Climate change 2014: synthesis report," in Contribution of Working Groups I, II and III to the Fifth Assessment Report of the Intergovernmental Panel on Climate Change, eds R. K. Pachauri and L. A. Meyer (Geneva: IPCC), 151.

Jacks, G. (2019). Drainage in Sweden -the past and new developments. Acta Agric. Scand. Sect. B Soil Plant Sci. 69, 405-410. doi: 10.1080/09064710.2019.1586 991

Jägerbrand, A. K., and Alatalo, J. M. (2015). Effects of human trampling on abundance and diversity of vascular plants, bryophytes and lichens in alpine heath vegetation, Northern. SpringerPlus 4:95. doi: 10.1186/s40064-015-0876-z

Janssen, P., Stella, J. C., Piégay, H., Räpple, B., Pont, B., Faton, J. M., et al. (2020). Divergence of riparian forest composition and functional traits from natural succession along a degraded river with multiple stressor legacies. Sci. Total Environ. 721:137730. doi: 10.1016/j.scitotenv.2020.137730

Jansson, R., Nilsson, C., and Renöfält, B. M. (2000b). Fragmentation of riparian floras in rivers with multiple dams. Ecology 81, 899-903.

Jansson, R., Nilsson, C., Dynesius, M., and Andersson, E. (2000a). Effects of river regulation on river-margin vegetation: a comparison of eight boreal rivers. Ecol. Appl. 10, 203-224.

Jansson, R., Ström, L., and Nilsson, C. (2019). Smaller future floods imply less habitat for riparian plants along a boreal river. Ecol. Appl. 29:e01977. doi: 10.1002/eap.1977

Jansson, R., Zinko, U., Merritt, D. M., and Nilsson, C. (2005). Hydrochory increases riparian plant species richness: a comparison between a free-flowing and a regulated river. J. Ecol. 93, 1094-1103. doi: 10.1111/j.1365-2745.2005.01057.x

Jauni, M., Gripenberg, S., and Ramula, S. (2015). Non-native plant species benefit from disturbance: a meta-analysis. Oikos 124, 122-129. doi: 10.1111/oik.01416

Johnson, R. K., and Almlöf, K. (2016). Adapting boreal streams to climate change: effects of riparian vegetation on water temperature and biological assemblages. Freshw. Sci. 35, 984-997. doi: 10.1086/687837

Jyväsjärvi, J., Koivunen, I., and Muotka, T. (2020). Does the buffer width matter: testing the effectiveness of forest certificates in the protection of headwater stream ecosystems. For. Ecol. Manage. 478:118532. doi: 10.1016/j.foreco.2020. 118532

Kasvi, E., Lotsari, E., Kumpumäki, M., Dubrovin, T., and Veijalainen, N. (2019). Effects of climate change and flow regulation on the flow characteristics of a low-relief river within Southern Boreal climate area. Water 11:1827. doi: 10.3390/w11091827

Keller, R. P., Geist, J., Jeschke, J. M., and Kühn, I. (2011). Invasive species in Europe: ecology, status, and policy. Environ. Sci. Eur. 23:23. doi: 10.1186/2190-4715-2323

Kilpeläinen, A., Kellomäki, S., Strandman, H., and Venäläinen, A. (2010). Climate change impacts on forest fire potential in boreal conditions in Finland. Clim. Change 103, 383-398. doi: 10.1007/s10584-009-9788-7

Kominoski, J. S., Follstad Shah, J. J., Canhoto, C., Fischer, D. G., Giling, D. P., González, E., et al. (2013). Forecasting functional implications of global changes in riparian plant communities. Front. Ecol. Environ. 11, 423-432. doi: 10.1890/ 120056 
Kuglerová, L., Jansson, R., Ågren, A., Laudon, H., and Renöfält, B. M. (2014b). Groundwater discharge creates hotspots of riparian plant species richness in a boreal forest stream network. Ecology 95, 715-725. doi: 10.1890/13-0363.1

Kuglerová, L., Ågren, A., Jansson, R., and Laudon, H. (2014a). Towards optimizing riparian buffer zones: ecological and biogeochemical implications for forest management. For. Ecol. Manage. 334, 74-84. doi: 10.1016/j.foreco.2014.08.033

Kuglerová, L., Botková, K., and Jansson, R. (2017). Responses of riparian plants to habitat changes following restoration of channelized streams. Ecohydrology 10:e1798. doi: 10.1002/eco.1798

Kuglerová, L., Hasselquist, E. M., Sponseller, R. A., Muotka, T., Hallsby, G., and Laudon, H. (2021). Multiple stressors in small streams in the forestry context of Fennoscandia: the effects in time and space. Sci. Total Environ. 756:143521. doi: 10.1016/j.scitotenv.2020.143521

Kuglerová, L., Jyväsjärvi, J., Ruffing, C., Muotka, T., Jonsson, A., Andersson, E., et al. (2020). Cutting edge: a comparison of contemporary practices of riparian buffer retention around small streams in Canada, Finland, and Sweden. Water Resour. Res. 56:e2019WR026381. doi: 10.1029/2019WR026381

Langston, N. (2013). Mining the boreal north. Am. Sci. 101, 98-102. doi: 10.1511/ 2013.101.98

Lapin, K., Bacher, S., Cech, T., Damjanić, R., Essl, F., Georges, F., et al. (2021). Comparing environmental impacts of alien plants, insects and pathogens in protected riparian forests. NeoBiota 69, 1-28. doi: 10.3897/neobiota.69.71651

Laudon, H., Sponseller, R. A., and Bishop, K. (2021). From legacy effects of acid deposition in boreal streams to future environmental threats. Environ. Res. Lett. 16:015007. doi: 10.1088/1748-9326/abd064

Lazdinis, M., and Angelstam, P. (2005). Functionality of riparian forest ecotones in the context of former Soviet Union and Swedish forest management histories. For. Policy Econ. 7, 321-332. doi: 10.1016/S1389-9341(03)00069-8

Ledesma, J. L. J., Futter, M. N., Blackburn, M., Lidman, F., Grabs, T., Sponseller, R. A., et al. (2018). Towards an improved conceptualization of riparian zones in boreal forest headwaters. Ecosystems 21, 297-315. doi: 10.1007/s10021-0170149-5

Lejon, A. G. C., Renöfält, B. M., and Nilsson, C. (2009). Conflicts associated with dam removal in Sweden. Ecol. Soc. 14:4. doi: 10.5751/ES-02931-140204

Leppänen, J. J., Weckström, J., and Korhola, A. (2017). Multiple mining impacts induce widespread changes in ecosystem dynamics in a boreal lake. Sci. Rep. 7:10581. doi: 10.1038/s41598-017-11421-8

Leskinen, P., Lindner, M., Verkerk, P. J., Nabuurs, G., and Wunder, S. (2020). Russian Forests And Climate Change, Vol. 11. Joensuu: European Forest Institute. doi: 10.36333/wsctu11

Lind, L., Hasselquist, E. M., and Laudon, H. (2019). Towards ecologically functional riparian zones: a meta-analysis to develop guidelines for protecting ecosystem functions and biodiversity in agricultural landscapes. J. Environ. Manage. 249:109391. doi: 10.1016/j.jenvman.2019.109391

Lind, L., and Nilsson, C. (2015). Vegetation patterns in small boreal streams relate to ice and winter floods. J. Ecol. 103, 431-440. doi: 10.1111/1365-2745.12355

Lind, L., Nilsson, C., Polvi, L. E., and Weber, C. (2014a). The role of ice dynamics in shaping vegetation in flowing waters. Biol. Rev. 89, 791-804. doi: 10.1111/brv. 12077

Lind, L., Nilsson, C., and Weber, C. (2014b). Effects of ice and floods on vegetation in streams in cold regions: implications for climate change. Ecol. Evol. 4, 4173-4184. doi: 10.1002/ece3.1283

Lindqvist, O., Johansson, K., Bringmark, L., Timm, B., Aastrup, M., Andersson, A., et al. (1991). Mercury in the Swedish environment - Recent research on causes, consequences and corrective methods. Water Air Soil Pollut. 55, xi-261. doi: 10.1007/BF00542429

Lindström, G. (1993). Floods in Sweden - Trends and Occurrence (Issue RH No. 6). Norrköping: SMHI.

Lisius, G. L., Snyder, N. P., and Collins, M. J. (2018). Vegetation community response to hydrologic and geomorphic changes following dam removal. River Res. Appl. 34, 317-327. doi: 10.1002/rra.3261

Lonsdale, W. M. (1999). Global patterns of plant invasions and the concept of invasibility. Ecology 80, 1522-1536.

Lozanovska, I., Bejarano, M. D., Martins, M. J., Nilsson, C., Ferreira, M. T., and Aguiar, F. C. (2020). Functional diversity of riparian woody vegetation is less affected by river regulation in the Mediterranean than boreal region. Front. Plant Sci. 11:857. doi: 10.3389/fpls.2020.00857
Lughadha, E. N., Bachman, S. P., Leão, T. C. C., Forest, F., Halley, J. M., Moat, J., et al. (2020). Extinction risk and threats to plants and fungi. Plants People Planet 2, 389-408. doi: 10.1002/ppp3.10146

Luke, S. H., Luckai, N. J., Burke, J. M., and Prepas, E. E. (2007). Riparian areas in the Canadian boreal forest and linkages with water quality in streams. Environ. Rev. 15, 79-97. doi: 10.1139/A07-001

Lytle, D. A., and Poff, N. L. (2004). Adaptation to natural flow regimes. Trends Ecol. Evol. 19, 94-100. doi: 10.1016/j.tree.2003.10.002

MacDonald, R. L., Chen, H. Y. H., Palik, B. P., and Prepas, E. E. (2014). Influence of harvesting on understory vegetation along a boreal riparian-upland gradient. For. Ecol. Manage. 312, 138-147. doi: 10.1016/j.foreco.2013.10.011

Mack, R. N., Simberloff, D., Lonsdale, W. M., Evans, H., Clout, M., and Bazzaz, F. A. (2000). Biotic Invasions: causes, epidemiology, global consequences, and control. Ecol. Appl. 10, 689-710.

Madej, M. A., Weaver, W. E., and Hagans, D. K. (1994). Analysis of bank erosion on the Merced River, Yosemite Valley, Yosemite National Park, California, USA. Environ. Manage. 18, 235-250. doi: 10.1007/BF02393764

Mäenpää, H., Peura, M., Halme, P., Siitonen, J., Mönkkönen, M., and Oldén, A. (2020). Windthrow in streamside key habitats: effects of buffer strip width and selective logging. For. Ecol. Manage. 475:118405. doi: 10.1016/j.foreco.2020. 118405

Mallik, A. U., Kreutzweiser, D. P., Spalvieri, C. M., and Mackereth, R. W. (2013). Understory plant community resilience to partial harvesting in riparian buffers of central Canadian boreal forests. For. Ecol. Manage. 289, 209-218. doi: 10. 1016/j.foreco.2012.09.039

Mallik, A. U., and Richardson, J. S. (2009). Riparian vegetation change in upstream and downstream reaches of three temperate rivers dammed for hydroelectric generation in British Columbia, Canada. Ecol. Eng. 35, 810-819. doi: 10.1016/j. ecoleng.2008.12.005

Manning, R. E. (1979). Impacts of recreation on riparian soils and vegetation. J. Am. Water Resour. Assoc. 15, 30-43. doi: 10.1111/j.1752-1688.1979.tb00287.x

Marinich, A., and Powell, K. (2017). Scots Pine (Pinus sylvestris)- Best Management Practices in Ontario. Peterborough: Ontario Invasive Plant Council.

Merritt, D. M., Nilsson, C., and Jansson, R. (2010). Consequences of propagule dispersal and river fragmentation for riparian plant community diversity and turnover. Ecol. Monogr. 80, 609-626. doi: 10.1890/09-1533.1

Merritt, D. M., and Wohl, E. E. (2006). Plant dispersal along rivers fragmented by dams. River Res. Appl. 22, 1-26. doi: 10.1002/rra.890

Miro (2021). Miro (version 0.7.1.0) Miro. Available online at: https://miro.com/ apps/

Monz, C. A. (2002). The response of two arctic tundra plant communities to human trampling disturbance. J. Environ. Manage. 64, 207-217. doi: 10.1006/jema. 2001.0524

Muotka, T., and Syrjänen, J. (2007). Changes in habitat structure, benthic invertebrate diversity, trout populations and ecosystem processes in restored forest streams: a boreal perspective. Freshw. Biol. 52, 724-737. doi: 10.1111/j. 1365-2427.2007.01727.x

Naiman, R. J., and Décamps, H. (1997). The ecology of interfaces: riparian zones. Ann. Rev. Ecol. Syst. 28, 621-658. doi: 10.1146/annurev.ecolsys.28.1. 621

Naiman, R. J., Décamps, H., and McClain, M. E. (2005). Riparia. Ecology, Conservation, and Management of Streamside Communities. Cambridge: Academic Press, doi: 10.1016/B978-0-12-663315-3.X5000-X

Natural Resources Canada (2020). Energy Fact Book. Ottawa: Natural Resources Canada.

Naturvårdsverket (2009). Betydelse Av Pentaklorfenolbehandlat Trä För Spridning Av Dioxiner I Miljön.

Newaz, M. S., Mallik, A. U., and Mackereth, R. W. (2019). Riparian vegetation recovery in a 23 year chronosequence of clear-cuts along boreal headwater streams. For. Ecol. Manage. 443, 69-83. doi: 10.1016/j.foreco.2019. 04.010

Ni, M., Deane, D. C., Li, S., Wu, Y., Sui, X., Xu, H., et al. (2021). Invasion success and impacts depend on different characteristics in non-native plants. Divers. Distrib. 27, 1194-1207. doi: 10.1111/ddi.13267

Nilsson, C. (1999). "Rivers and streams," in Swedish Plant Geography, eds H. Rydin, P. Snoeijs, and M. Diekmann (Ethiopia: Opulus Press), 135-148. 
Nilsson, C., Brown, R. L., Jansson, R., and Merritt, D. M. (2010). The role of hydrochory in structuring riparian and wetland vegetation. Biol. Rev. 85, 837-858. doi: 10.1111/j.1469-185X.2010.00129.x

Nilsson, C., Ekblad, A., Gardfjell, M., and Carlberg, B. (1991). Long-term effects of river regulation on river margin vegetation. J. Appl. Ecol. 28, 963-987. doi: $10.2307 / 2404220$

Nilsson, C., and Jansson, R. (1995). Floristic differences between riparian corridors of regulated and free-flowing boreal rivers. Regul. Rivers 11, 55-66. doi: 10.1002/ rrr.3450110106

Nilsson, C., Jansson, R., Kuglerová, L., Lind, L., and Ström, L. (2013). Boreal riparian vegetation under climate change. Ecosystems 16, 401-410. doi: 10.1007/ s10021-012-9622-3

Nilsson, C., Jansson, R., and Zinko, U. (1997). Long-term responses of river-margin vegetation to water-level regulation. Science 276, 798-800. doi: 10.1126/science. 276.5313 .798

Nilsson, C., Pizzuto, J. E., Moglen, G. E., Palmer, M. A., Stanley, E. H., Bockstael, N. E., et al. (2003). Ecological forecasting and the urbanization of stream ecosystems: challenges for economists, hydrologists, geomorphologists, and ecologists. Ecosystems 6, 659-674. doi: 10.1007/s10021-002-0217-2

Nilsson, C., Polvi, L. E., Gardeström, J., Hasselquist, E. M., Lind, L., and Sarneel, J. M. (2015a). Riparian and in-stream restoration of boreal streams and rivers: success or failure? Ecohydrology 8, 753-764. doi: 10.1002/eco.1480

Nilsson, C., Polvi, L. E., and Lind, L. (2015b). Extreme events in streams and rivers in arctic and subarctic regions in an uncertain future. Freshw. Biol. 60, 2535-2546. doi: 10.1111/fwb.12477

Nilsson, C., Reidy, C. A., Dynesius, M., and Revenga, C. (2005). Fragmentation and flow regulation of the world's large river systems. Science 308, 405-408. doi: 10.1126/science.1107887

Nilsson, C., Sarneel, J. M., Palm, D., Gardeström, J., Pilotto, F., Polvi, L. E., et al. (2017). How Do Biota Respond to Additional Physical Restoration of Restored Streams? Ecosystems 20, 144-162. doi: 10.1007/s10021-016-0020-0

Nilsson, C., and Svedmark, M. (2002). Basic principles and ecological consequences of changing water regimes: riparian plant communities. Environ. Manag. 30, 468-480. doi: 10.1007/s00267-002-2735-2

Nybø, S., Certain, G., and Skarpaas, O. (2012). The Norwegian Nature Index state and trends of biodiversity in Norway. Nor. Geogr. Tidsskr. 66, 241-249. doi: 10.1080/00291951.2012.743168

Oldén, A., Selonen, V. A. O., Lehkonen, E., and Kotiaho, J. S. (2019). The effect of buffer strip width and selective logging on streamside plant communities. BMC Ecol. 19:9. doi: 10.1186/s12898-019-0225-0

OneGeology (2020). One Geology Portal. Available online at: http://portal. onegeology.org/OnegeologyGlobal/ (accessed October 15, 2021).

Östlund, L., Zackrisson, O., and Axelsson, A.-L. (1997). The history and transformation of a Scandinavian boreal forest landscape since the 19th century. Can. J. For. Res. 27, 1198-1206. doi: 10.1139/cjfr-27-8-1198

Påhlsson, A. B. (1989). Toxicity of heavy metals ( $\mathrm{Zn}, \mathrm{Cu}, \mathrm{Cd}, \mathrm{Pb})$ to vascular plants. Water Air Soil Pollut. 47, 287-319. doi: 10.1007/BF00279329

Palmer, M. A., Reidy Liermann, C. A., Nilsson, C., Flörke, M., Alcamo, J., Lake, P. S., et al. (2008). Climate change and the world's river basins: anticipating management options. Front. Ecol. Environ. 6, 81-89. doi: 10.1890/060148

Pattison, Z., Minderman, J., Boon, P. J., and Willby, N. (2017). Twenty years of change in riverside vegetation: what role have invasive alien plants played? Appl. Veg. Sci. 20, 422-434. doi: 10.1111/avsc. 12297

Perry, L. G., Shafroth, P. B., Hay, L. E., Markstrom, S. L., and Bock, A. R. (2020). Projected warming disrupts the synchrony of riparian seed release and snowmelt streamflow. New Phytol. 225, 693-712. doi: 10.1111/nph.16191

Pfadenhauer, J. S., and Klötzli, F. A. (2020). Global Vegetation. Fundamentals, Ecology and Distribution. Berlin: Springer.

Pickett, S. T. A. (1989). "Space-for-time substitution as an alternative to long-term studies," in Long-Term Studies in Ecology, ed. G. E. Likens (Berlin: SpringerVerlag), 110-135. doi: 10.1007/978-1-4615-7358-6_5

Planty-Tabacchi, A. M., Tabacchi, E., Naiman, R. J., and Deferrari, C. (1996). Invasibility of species-rich communities in riparian zones. Conserv. Biol. 10, 598-607. doi: 10.1046/j.1523-1739.1996.10020598.x

Poff, B., Koestner, K. A., Neary, D. G., and Henderson, V. (2011). Threats to riparian ecosystems in Western North America: an analysis of existing literature. J. Am. Water Resour. Assoc. 47, 1241-1254. doi: 10.1111/j.1752-1688. 2011.00571.x

Poff, N. L., and Zimmerman, J. K. H. (2010). Ecological responses to altered flow regimes: a literature review to inform the science and management of environmental flows. Freshw. Biol. 55, 194-205. doi: 10.1111/j.1365-2427.2009. 02272.x

Polvi, L. E., Lind, L., Persson, H., Miranda-Melo, A., Pilotto, F., Su, X., et al. (2020). Facets and scales in river restoration: nestedness and interdependence of hydrological, geomorphic, ecological, and biogeochemical processes. J. Environ. Manage. 265:110288. doi: 10.1016/j.jenvman.2020.110288

Qiu, G., Feng, X., Wang, S., and Shang, L. (2005). Mercury and methylmercury in riparian soil, sediments, mine-waste calcines, and moss from abandoned $\mathrm{Hg}$ mines in east Guizhou province, southwestern China. Appl. Geochem. 20, 627-638. doi: 10.1016/j.apgeochem.2004.09.006

Ranjan, J., Joshi, V., Mandal, T., and Mandal, D. D. (2021). Ecotoxicological risk assessment of pentachlorophenol, an emerging DBP to plants: evaluation of oxidative stress and antioxidant responses. Environ. Sci. Pollut. Res. 28, 27954-27965. doi: 10.1007/s11356-021-12578-6

Ravot, C., Laslier, M., Hubert-Moy, L., Dufour, S., Le Coeur, D., and Bernez, I. (2020). Large dam removal and early spontaneous riparian vegetation recruitment on alluvium in a former reservoir: lessons learned from the preremoval phase of the Sélune River project (France). River Res. Appl. 36, 894-906. doi: 10.1002/rra.3535

Renöfält, B. M., Jansson, R., and Nilsson, C. (2005). Spatial patterns of plant invasiveness in a riparian corridor. Landsc. Ecol. 20, 165-176. doi: 10.1007/ s10980-004-2262-z

Renöfält, B. M., Jansson, R., and Nilsson, C. (2010). Effects of hydropower generation and opportunities for environmental flow management in Swedish riverine ecosystems. Freshw. Biol. 55, 49-67. doi: 10.1111/j.1365-2427.2009. 02241.x

Richardson, D. M., Holmes, P. M., Esler, K. J., Galatowitsch, S. M., Stromberg, J. C., Kirkman, S. P., et al. (2007). Riparian vegetation: degradation, alien plant invasions, and restoration prospects. Divers. Distrib. 13, 126-139. doi: 10.1111/ j.1472-4642.2006.00314.x

Richardson, D. M., and Rejmánek, M. (2004). Conifers as invasive aliens: a global survey and predictive framework. Divers. Distrib.10, 321-331. doi: 10.1111/j. 1366-9516.2004.00096.x

Riis, T., Kelly-Quinn, M., Aguiar, F. C., Manolaki, P., Bruno, D., Bejarano, M. D., et al. (2020). Global overview of ecosystem services provided by riparian vegetation. BioScience 70, 501-514. doi: 10.1093/biosci/biaa041

Ronzhina, D. A. (2020). Ecological differentiation between invasive and native species of the genus epilobium in riparian ecosystems is associated with plant functional traits. Russ. J. Biol. Invasions 11, 132-142. doi: 10.1134/ S2075111720020071

Rood, S. B., Scott, M. L., Dixon, M., González, E., Marks, C. O., Shafroth, P. B., et al. (2020). Ecological interfaces between land and flowing water: themes and trends in riparian research and management. Wetlands 40, 1801-1811. doi: 10.1007/s13157-020-01392-4

Rose, M., and Hermanutz, L. (2004). Are boreal ecosystems susceptible to alien plant invasion? Evidence from protected areas. Oecologia 139, 467-477. doi: 10.1007/s00442-004-1527-1

Ruwanza, S., Gaertner, M., Esler, K. J., and Richardson, D. M. (2013). The effectiveness of active and passive restoration on recovery of indigenous vegetation in riparian zones in the Western Cape, South Africa: a preliminary assessment. S. Afr. J. Bot. 88, 132-141. doi: 10.1016/j.sajb.2013.06.022

Sabo, J. L., Sponseller, R., Dixon, M., Gade, K., Harms, T., Jani, A., et al. (2005). Riparian zones increase regional species richness by harboring different, not more, species. Ecology 86, 56-62. doi: 10.1890/04-0668

Saint-Laurent, D., Hähni, M., St-Laurent, J., and Baril, F. (2010). Comparative assessment of soil contamination by lead and heavy metals in riparian and agricultural areas (Southern Québec, Canada). Int. J. Environ. Res. Public Health 7, 3100-3114. doi: 10.3390/ijerph7083100

Sarneel, J. M., Hefting, M. M., Kowalchuk, G. A., Nilsson, C., Van der Velden, M., Visser, E. J. W., et al. (2019b). Alternative transient states and slow plant community responses after changed flooding regimes. Global Change Biol. 25, 1358-1367. doi: 10.1111/gcb.14569

Sarneel, J. M., Bejarano, M. D., Van Oosterhout, M., and Nilsson, C. (2019a). Local flooding history affects plant recruitment in riparian zones. J. Veg. Sci. 30, 224-234. doi: 10.1111/jvs.12731

Sarneel, J. M., Kardol, P., and Nilsson, C. (2016). The importance of priority effects for riparian plant community dynamics. J. Veg. Sci. 27, 658-667. doi: 10.1111 /jvs. 12412

Schafft, M., Wegner, B., Meyer, N., Wolter, C., and Arlinghaus, R. (2021). Ecological impacts of water-based recreational activities on freshwater ecosystems: a global 
meta-analysis. Proc. R. Soc. B Biol. Sci. 288:20211623. doi: 10.1098/rspb.2021. 1623

Schipper, A. M., Lotterman, K., Leuven, R. S. E. W., Ragas, A. M. J., De Kroon, H., and Hendriks, A. J. (2011). Plant communities in relation to flooding and soil contamination in a lowland Rhine River floodplain. Environ. Pollut. 159, 182-189. doi: 10.1016/j.envpol.2010.09.006

Shafroth, P. B., Friedman, J. M., Auble, G. T., Scott, M. L., and Braatne, J. H. (2002). Potential responses of riparian vegetation to dam removal. BioScience 52, 703-712. doi: 10.1641/0006-35682002052[0703:PRORVT]2.0.CO;2

Simberloff, D. (2011). How common are invasion-induced ecosystem impacts? Biol. Invasions 13, 1255-1268. doi: 10.1007/s10530-011-9956-3

Singh, R., Tiwari, A. K., and Singh, G. S. (2021). Managing riparian zones for river health improvement: an integrated approach. Landsc. Ecol. Eng. 17, 195-223. doi: 10.1007/s11355-020-00436-5

Smokorowski, K. E. (2021). The ups and downs of hydropeaking: a Canadian perspective on the need for, and ecological costs of, peaking hydropower production. Hydrobiologia 849, 421-441. doi: 10.1007/s10750-020-04480-y

Sonesson, J., Ring, E., Högbom, L., Lämås, T., Widenfalk, O., Mohtashami, S., et al. (2020). Costs and benefits of seven alternatives for riparian forest buffer management. Scand. J. For. Res. 36, 135-143. doi: 10.1080/02827581.2020. 1858955

Sponseller, R. A., Temnerud, J., Bishop, K., and Laudon, H. (2014). Patterns and drivers of riverine nitrogen $(\mathrm{N})$ across alpine, subarctic, and boreal Sweden. Biogeochemistry 120, 105-120. doi: 10.1007/s10533-014-9984-z

Stella, J. C., Battles, J. J., Orr, B. K., and McBride, J. R. (2006). Synchrony of seed dispersal, hydrology and local climate in a semi-arid river reach in California. Ecosystems 9, 1200-1214. doi: 10.1007/s10021-005-0138-y

Stella, J. C., and Bendix, J. (2019). "Multiple Stressors in Riparian Ecosystems," in Multiple Stressors in River Ecosystems, eds S. Sabater, A. Elosegi, and R. Ludwig (Amsterdam: Elsevier), 81-110. doi: 10.1016/B978-0-12-811713-2.09991-X

Stine, P. A., Hessburg, P. F., Spies, T. A., Kramer, M., Fettig, C. J., Hansen, A., et al. (2014). The Ecology And Management of Moist Mixed-Conifer Forests In Eastern Oregon and Washington, A Synthesis of The Relevant Science and Implications For Future Land Management. Washington, DC:: USDA Forest Service.

Stocks, B. J., Fosberg, M. A., Lynham, T. J., Mearns, L., Wotton, B. M., Yang, Q., et al. (1998). Climate change and forest fire potential in Russian and Canadian boreal forests. Clim. Change 38, 1-13. doi: 10.1023/A:1005306001055

Stoler, A., Sudol, K., Mruzek, J., and Relyea, R. (2018). Interactive effects of road salt and sediment disturbance on the productivity of seven common aquatic macrophytes. Freshw. Biol. 63, 709-720. doi: 10.1111/fwb.13110

Ström, L., Jansson, R., and Nilsson, C. (2012). Projected changes in plant species richness and extent of riparian vegetation belts as a result of climate-driven hydrological change along the Vindel River in Sweden. Freshw. Biol. 57, 49-60. doi: $10.1111 /$ j.1365-2427.2011.02694.x

Ström, L., Jansson, R., and Nilsson, C. (2014). Invasibility of boreal wetland plant communities. J. Veg. Sci. 25, 1078-1089. doi: 10.1111/jvs.12157

Ström, L., Jansson, R., Nilsson, C., Johansson, M. E., and Xiong, S. (2011). Hydrologic effects on riparian vegetation in a boreal river: an experiment testing climate change predictions. Global Change Biol. 17, 254-267. doi: 10.1111/j. 1365-2486.2010.02230.x

Teutschbein, C., Grabs, T., Karlsen, R. H., Laudon, H., and Bishop, K. H. (2015). Hydrological response to changing climate conditions: spatial streamflow variability in the boreal region. Water Resour. Res. 15, 9425-9446. doi: 10.1002/ 2015WR017337

Tickner, D. P., Angold, P. G., Gurnell, A. M., and Mountford, J. O. (2001). Riparian plant invasions: hydrogeomorphological control and ecological impacts. Prog. Phys. Geogr. 25, 22-52. doi: 10.1177/030913330102500102

Timoney, K. P., Peterson, G., and Wein, R. (1997). Vegetation development of boreal riparian plant communities after flooding, fire, and logging, Peace River, Canada. For. Ecol. Manage. 93, 101-120. doi: 10.1016/S0378-1127(96)03929-1

Tolkkinen, M. J., Heino, J., Ahonen, S. H. K., Lehosmaa, K., and Mykrä, H. (2020). Streams and riparian forests depend on each other: a review with a special focus on microbes. For. Ecol. Manag. 462:117962. doi: 10.1016/j.foreco.2020.117962

Tonkin, J. D., Merritt, D. M., Olden, J. D., Reynolds, L. V., and Lytle, D. A. (2018). Flow regime alteration degrades ecological networks in riparian ecosystems. Nat. Ecol. Evol. 2, 86-93. doi: 10.1038/s41559-017-0379-0

Truchy, A., Angeler, D. G., Sponseller, R. A., Johnson, R. K., and McKie, B. G. (2015). Linking biodiversity, ecosystem functioning and services, and ecological resilience: towards an integrative framework for improved management. $A d v$. Ecol. Res. 53, 55-96. doi: 10.1016/bs.aecr.2015.09.004

Tullos, D. D., Collins, M. J., Bellmore, J. R., Bountry, J. A., Connolly, P. J., Shafroth, P. B., et al. (2016). Synthesis of common management concerns associated with dam removal. J. Am. Water Resour. Assoc. 52, 1179-1206. doi: 10.1111/17521688.12450

Turner, M. G., and Gardner, R. H. (Eds). (2015). "Landscape disturbance dynamics," in Landscape Ecology in Theory and Practice, 2nd Edn, (Berlin: Springer-Verlag), 175-228. doi: 10.1007/978-1-4939-2794-4_6

United Nations Department of Economic and Social Affairs Population Division (2018). World Urbanization Prospects: The 2018 Revision. Available online at: https://population.un.org/wup/Country-Profiles/ (accessed October 11, 2021).

Van Oorschot, M., Kleinhans, M., Buijse, T., Geerling, G., and Middelkoop, H. (2018). Combined effects of climate change and dam construction on riverine ecosystems. Ecol. Eng. 120, 329-344. doi: 10.1016/j.ecoleng.2018.05.037

Vesipa, R., Camporeale, C., and Ridolfi, L. (2017). Effect of river flow fluctuations on riparian vegetation dynamics: processes and models. Adv. Water Resour. 110, 29-50. doi: 10.1016/j.advwatres.2017.09.028

Walsh, C. J., Roy, A. H., Feminella, J. W., Cottingham, P. D., Groffman, P. M., and Morgan, R. P. (2005). The urban stream syndrome: current knowledge and the search for a cure. J. North Am. Benthol. Soc. 24, 706-723. doi: 10.1899/04-028.1

Walsh, J. E., Ballinger, T. J., Euskirchen, E. S., Hanna, E., Mård, J., Overland, J. E., et al. (2020). Extreme weather and climate events in northern areas: a review. Earth Sci. Rev. 209:103324. doi: 10.1016/j.earscirev.2020.103324

Warren, R. J., Potts, D. L., and Frothingham, K. M. (2015). Stream structural limitations on invasive communities in Urban Riparian Areas. Invasive Plant Sci. Manag. 8, 353-362. doi: 10.1614/ipsm-d-14-00081.1

Wells, J. V., Dawson, N., Culver, N., Reid, F. A., and Morgan Siegers, S. (2020). The state of conservation in North America's boreal forest: issues and opportunities. Front. For. Glob. Change 3:90. doi: 10.3389/ffgc.2020.00090

Wheeler, A. P., Angermeier, P. L., and Rosenberger, A. E. (2005). Impacts of new highways and subsequent landscape urbanization on stream habitat and biota. Rev. Fish. Sci. 13, 141-164. doi: 10.1080/10641260590964449

Willard, B. E., Cooper, D. J., and Forbes, B. C. (2007). Natural regeneration of alpine tundra vegetation after human trampling: a 42-year data set from Rocky Mountain National Park, Colorado, U.S.A. Arct. Antarct. Alp. Res. 39, 177-183. doi: 10.1657/1523-0430200739[177:NROATV]2.0.CO;2

Wohl, E. (2017). Connectivity in rivers. Prog. Phys. Geogr. 41, 345-362. doi: 10. 1177/0309133317714972

Wohl, E., and Beckman, N. D. (2014). Leaky rivers: implications of the loss of longitudinal fluvial disconnectivity in headwater streams. Geomorphology 205, 27-35. doi: 10.1016/j.geomorph.2011.10.022

Woo, M. K., Thorne, R., Szeto, K., and Yang, D. (2008). Streamflow hydrology in the boreal region under the influences of climate and human interference. Phil. Trans. R. Soc. B Biol. Sci. 363, 2251-2260. doi: 10.1098/rstb.2007.2197

Yarnell, S. M., Petts, G. E., Schmidt, J. C., Whipple, A. A., Beller, E. E., Dahm, C. N., et al. (2015). Functional flows in modified riverscapes: hydrographs, habitats and opportunities. BioScience 65, 963-972. doi: 10.1093/biosci/biv102

Zelnik, I., Haler, M., and Gaberščik, A. (2015). Vulnerability of a riparian zone towards invasion by alien plants depends on its structure. Biologia 70, 869-878. doi: $10.1515 /$ biolog-2015-0110

Conflict of Interest: The authors declare that the research was conducted in the absence of any commercial or financial relationships that could be construed as a potential conflict of interest

Publisher's Note: All claims expressed in this article are solely those of the authors and do not necessarily represent those of their affiliated organizations, or those of the publisher, the editors and the reviewers. Any product that may be evaluated in this article, or claim that may be made by its manufacturer, is not guaranteed or endorsed by the publisher.

Copyright (c) 2022 Hoppenreijs, Eckstein and Lind. This is an open-access article distributed under the terms of the Creative Commons Attribution License (CC BY). The use, distribution or reproduction in other forums is permitted, provided the original author(s) and the copyright owner(s) are credited and that the original publication in this journal is cited, in accordance with accepted academic practice. No use, distribution or reproduction is permitted which does not comply with these terms. 